\title{
Understanding the Gender Earnings Gap: Hours Worked, Occupational Sorting, and Labor Market Experience
}

\author{
Maria Canon, Limor Golan, and Cody A. Smith
}

\begin{abstract}
This article documents life-cycle gender differences in labor market outcomes using longitudinal data of a cohort of individuals from the National Longitudinal Survey of Youth 1979. As in other datasets, the gender earnings gap increases with age. We find that hours worked and labor market experience are the most substantial observable variables in explaining the gender pay gap. We also focus on patterns in occupational changes over the life cycle, as a large part of pay growth occurs when workers change jobs. We find that college-educated men, on average, move into occupations with higher task complexity. We further show that women are less likely to change occupations. Moreover, on average, pay grows when workers change occupations, but the growth is smaller for women. Finally, we discuss theories that are consistent with the patterns we document. (JEL J16, J24, J31)
\end{abstract}

Federal Reserve Bank of St. Louis Review, Second Quarter 2021, 103(2), pp. 175-205.

https://doi.org/10.20955/r.103.175-205

\section{INTRODUCTION}

The labor force participation of women has increased substantially since the 1960s. At the same time, the gender earnings gap has declined from about 40 percent in the late 1960s to less than 28 percent in the early 1990s and has stopped converging since. ${ }^{1}$ Much of the gender earnings gap is explained by gender differences in labor force attachment and accumulated labor market experience. In particular, the gender earnings gap increases with age as the

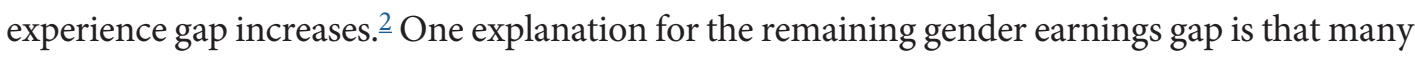
jobs disproportionately reward working long hours. $\frac{3}{3}$ In many jobs, the pay is nonlinear in hours worked and penalizes workers who choose to work fewer hours. This reward structure tends to affect women of childbearing years disproportionately and also affects their occupational choices. Furthermore, in most occupations, the representation of women at the top-paying jobs is low-even if at lower levels there are many women. ${ }^{4}$

Maria Canon is a senior lecturer at Washington University in St. Louis. Limor Golan is a professor at Washington University in St. Louis and a research fellow at the Federal Reserve Bank of St. Louis. Cody A. Smith is a PhD candidate at Washington University in St. Louis.

(c) 2021, Federal Reserve Bank of St. Louis. The views expressed in this article are those of the author(s) and do not necessarily reflect the views of the Federal Reserve System, the Board of Governors, or the regional Federal Reserve Banks. Articles may be reprinted, reproduced, published, distributed, displayed, and transmitted in their entirety if copyright notice, author name(s), and full citation are included. Abstracts, synopses, and other derivative works may be made only with prior written permission of the Federal Reserve Bank of St. Louis. 


\section{Canon, Golan, Smith}

This article documents the evolution of the gender earnings gap over the life cycle using data from a cohort of men and women from the National Longitudinal Survey of Youth 1979 (NLSY79). The pattern is similar to the one documented in other datasets: The gender pay gap increases with age. To understand the factors affecting this pattern, we explore the role of occupations, hours worked, and work experience accumulated with age in the observed gender earnings. While previous literature analyzed occupational and labor force participation patterns, we document not only those but also task assignments and changes in task assignments over the life cycle. $\underline{5}$ Previous literature did not analyze the evolution of task assignments and their changes over the life cycle in the context of the gender pay gap. Changes in occupational tasks and occupations are typically important to understanding the wage growth of workers over the life cycle. Our dataset allows us to account for both detailed labor supply history and heterogeneity in test scores and education.

Over time, as the earnings gap increases, the gap in weekly hours worked grows as well. This gap in hours is one of the factors that contributes to the increase in the earnings gap. We then study how occupations change over the life cycle. In particular, we explore whether the increase in the earnings gap is due to changes in occupational assignments and the evolution of the type of tasks workers are assigned. We also examine whether the occupational gap increases with age.

We define occupations along a unidimensional axis, measuring each occupation's demand for complex cognitive tasks. We focus on changes in nonroutine task complexity because over the life cycle workers typically transition into occupations with more cognitive task complexity and fewer motor skills requirements, which cause wages to increase (see Yamaguchi, 2012, for task analysis for men). We follow Antonovics and Golan (2012), who show that this transition is an important source of the increase in wage dispersion among white men, and Golan, Sanders, and James (2019) and Golan and Sanders (2019), who show that the transition is also an important source of the increase in the racial pay gap over the life cycle for men. We document that occupation matches and their pattern over the life cycle vary by education. As expected, workers with a college degree are matched with occupations of higher complexity than workers without a college degree.

We find that among workers with a college degree, men and women start in similar occupations. Over the life cycle, men surpass women in terms of the complexity of tasks performed. Among workers without a college degree, women start in higher-ranked occupations than men. Over the life cycle, these women remain ahead of these men. Thus, unlike the racial gaps and the increasing wage gaps for men, occupational task complexity may not explain much of the earnings gap for workers without a college degree.

The gender gaps above can be partly driven by differences in the observable and unobservable characteristics of men and women. We now analyze the role of differences between men and women based on observable characteristics in our data. A substantial gap in earnings remains after controlling for labor market experience, hours, Armed Forces Qualification Test (AFQT) scores, education, and occupation. We quantify the contribution of the different factors to the pay gap using the Blinder-Oaxca decomposition. Whereas a small difference in the earnings gap is explained by the compositional effects of college-educated men and women, 
the differences in hours and labor market experience account for the majority of the gender earnings gap for college- and noncollege-educated workers. Moreover, we find that in our sample, the increase in the earnings gap with age is associated with the increase in the labor market experience gap and the breaks in labor force participation for both college- and noncollege-educated workers. ${ }^{6}$ We discuss our findings in light of different explanations in the literature. The gaps in hours worked and as a result of experience accumulated may be a result of differences in preferences and roles that women play in caring for children. However, discrimination in the labor market and lack of opportunity and promotions may also lead to these choices. Gayle and Golan (2011) find evidence that while there are preference differences, discrimination plays an important role in the choices of hours worked and experience accumulated.

For college-educated women, we find that task complexity does not increase on average as much as it does for college-educated men (after the initial entry years). ${ }^{7}$ Job changes are an important factor contributing to wage growth over the life cycle. On average, workers' wages increase when they change jobs, regardless of whether they move to perform more- or lesscomplex tasks (see Antonovics and Golan, 2012). We first document that women change occupations less often than men do. We next document that wage growth is lower for women when they change occupations. We then discuss theories that are consistent with the patterns we document. In particular, we discuss human capital and learning and sorting models. One theory is that of learning by doing (e.g., Jovanovic and Nyarko, 1997): Workers learn how to perform tasks and accordingly move up the job ladder, causing wages to increase over time. A second theory is search frictions in the labor market: Workers may not always find the jobs that best suit their qualifications initially, but over time they search and change jobs when they find better matches for their skill set. Lastly, workers do not always know which type of job matches their skills best and they learn about their own skills with experience (e.g., Jovanovic, 1979; Miller, 1984; and Antonovics and Golan, 2012, among others). Working fewer hours can reduce the amount of both learning by doing and learning about one's skills and therefore slow down the sorting of women into jobs that better suit their skill sets (e.g., Taber and Venjlin, 2016, and Lise and Postel-Vinay, 2020). However, discrimination may also imply that women are less likely to receive attractive offers and, therefore, are less likely to switch jobs. Family considerations may also affect women's likelihood of changing jobs if it requires moving.

The article is organized as follows. Section 2 describes the data construction and necessary information about the sample. Section 3 documents the gender gaps in earnings, task assignments, and hours over the life cycle and discusses possible reasons for the patterns. Section 4 analyzes the role of observable differences in the gender pay gap. Section 5 documents job changes and discusses theories consistent with the patterns. Section 6 concludes.

\section{DATA}

Our sample contains weekly panel data on U.S. birth cohorts for 1957-64 from the NLSY79. In particular, our base sample uses the 2,477 white females and 2,439 white males from the cross-sectional sample. From the NLSY79, we use histories on wages, hours worked, 


\section{Canon, Golan, Smith}

three-digit job codes (the most disaggregated category from the 1970 Census coding system), level of education, age, gender, and AFQT scores.

Although the NLSY79 contains information on individuals' labor force activities for each week from 1978 through the most recent year in which a respondent was interviewed, we rely only on labor market data from 1978 through 2000 because of a switch in job coding that occurred after 2000. If a person is not interviewed in a given year (or years), then at the next interview date, the respondent is asked to go back and retrospectively report their labor force activities. As a result, the NLSY allows us to construct relatively complete work histories. The work history data include information on each of up to five jobs a respondent may have held in a given week. We define a person's job in a given week to be the job at which they worked the most number of hours, but we still report our variables as the sum of the values of all jobs held in a given week. We begin each person's history in the week they begin employment after completing their highest degree. We end each person's history at 780 weeks of potential experience because attrition from the sample makes it difficult to construct complete work histories for longer horizons.

Using hours worked per week, we construct weeks of part-time experience and weeks of full-time experience. We count weeks of part-time experience as all the weeks that hours worked per week $<35$. If hours worked per week are $\geq 35$, the week is counted as full-time experience. 9

Using the person's main job each week, we match the job with Antonovics and Golan's (2012) " $\alpha$ " index for complex task assignments at each job. To construct this task assignment index, Antonovics and Golan (2012) use the Dictionary of Occupational Titles (DOT) (U.S. Census Bureau, 1981), which has information on the primary tasks done in a given job and the worker qualities needed for job success. The job qualities given in the DOT are linked to the 1970 Census three-digit job codes in an augmented version of the April 1971 Current Population Survey. $\underline{10}$ The DOT is both comprehensive (describing 12,099 jobs) and detailed (along 44 dimensions). Antonovics and Golan (2012) run principal component analysis on the high-dimensional set of job measurements and take the first principal component, which seems to correspond to tasks that are nonroutine or complex, which are classified as jobs that require more skills that are hard to observe. They then construct their measure of $\alpha$, normalized by calculating its percentile ranking and dividing by 100 . This normalized predicted score takes on a value from 0.01 to 1.00 . Higher values reflect more skills required. The $\alpha$ index is then matched to the job data from the NLSY79.

We take as our initial sample the cross-sectional sample of 4,916:2,439 white males and 2,417 white females. We drop 887 respondents because we cannot identify either their highest degree or the date at which they received their highest degree; 653 respondents who completed their highest degree prior to the start date of the work history record; and 534 respondents who completed their highest degree relatively late in life, because we worry that these workers already may have accumulated substantial labor market experience that could influence employer's beliefs about skills. We also drop 52 respondents for whom we could not identify the start of their full-time employment and 326 respondents who had ever reported an hourly wage of either over $\$ 200$ or under $\$ 2$. We additionally drop 276 respondents for whom the worker history is relatively incomplete-in particular, respondents with more than 300 weeks 


\section{Table 1}

Sample Means and Differences

\begin{tabular}{|c|c|c|c|c|c|}
\hline & Variable & Men & Women & $\% \Delta$ & $p$-value $\Delta$ \\
\hline \multirow{2}{*}{ Pre-labor market } & AFQT score (raw) & 61 & 61 & 0 & 0.999 \\
\hline & AFQT score (normal) & 37 & 41 & 11 & $0.099 *$ \\
\hline \multirow{5}{*}{ First job } & Age & 21 & 21 & 0 & 0.251 \\
\hline & Wage $(\$ / h r)$ & 11 & 10 & -11 & $0.000^{* * *}$ \\
\hline & Earnings (\$/mo) & 1,815 & 1,428 & -21 & $0.000^{* * * *}$ \\
\hline & Full time (\%) & 80 & 69 & -14 & $0.000 * * *$ \\
\hline & $\alpha(\times 100)$ & 46 & 51 & 11 & $0.000^{* * *}$ \\
\hline \multirow{6}{*}{ Current job } & Age & 28 & 28 & 0 & 0.244 \\
\hline & Wage $(\$ / h r)$ & 17 & 14 & -19 & $0.000^{* * *}$ \\
\hline & Earnings (\$/mo) & 3,065 & 2,089 & -32 & $0.000^{* * *}$ \\
\hline & Labor (hrs/wk) & 42 & 34 & -20 & $0.000 * * *$ \\
\hline & Labor (hrs/mo) & 176 & 149 & -16 & $0.000^{* * * *}$ \\
\hline & $\alpha(\times 100)$ & 55 & 60 & 9 & $0.000^{* * *}$ \\
\hline \multirow{4}{*}{ Experience } & Part time (wks) & 23 & 63 & 179 & $0.000^{* * *}$ \\
\hline & Full time (wks) & 323 & 268 & -17 & $0.000^{* * *}$ \\
\hline & Job spells & 12.0 & 11 & -7 & $0.003^{* *}$ \\
\hline & $N$ & 1,187 & 1,001 & -16 & \\
\hline
\end{tabular}

in which they did not work or with missing work information during the first 600 weeks following their transition to full-time work; that is, we give respondents 600 weeks in which to accumulate 300 weeks of valid work information, otherwise we drop them from the sample. After these drops, we are left with 2,188 individuals: 1,001 females and 1,187 males. Relative to the initial sample, these workers are young and have strong attachment to the labor force.

\subsection{Summary Statistics}

Table 1 provides summary statistics. On average, women's monthly earnings are 68 percent of men's. About 41 percent of women have a college degree or more, compared with 37 percent of men. Average monthly hours are 16 percent lower for women, and woman accumulate on average 41 more weeks of part-time experience and 54 fewer weeks of full-time experience than men. Women enter the labor market with wages that are on average 11 percent lower than men's. Those differences persist and compounds over the life cycle: Women's wages are on average 19 percent lower than men's. Women are 53 percent more likely to enter the labor market as a part-time worker. They are slightly older than men by 7.5 weeks, which is expected from their college attainment gap (8.6 percent, or 3.5 percentage points) multiplied by a standard four-year college education. 
Table 2

Sample Means and Differences, College Degree

\begin{tabular}{|c|c|c|c|c|c|}
\hline & Variable & Men & Women & $\% \Delta$ & $p$-value \\
\hline \multirow{2}{*}{ Pre-labor market } & AFQT score (raw) & 80 & 77 & -4 & $0.023^{* *}$ \\
\hline & AFQT score (normal) & 0.7 & 0.6 & -15 & $0.023^{* *}$ \\
\hline \multirow{5}{*}{ First job } & Age & 24.0 & 24.0 & 0 & 0.879 \\
\hline & Wage $(\$ / h r)$ & 14.25 & 12.70 & -11 & $0.010^{* * *}$ \\
\hline & Earnings $(\$ / m o)$ & 2,359 & 1,914 & -19 & $0.000^{* * *}$ \\
\hline & Full time (\%) & 86 & 77 & -10 & $0.001^{* * *}$ \\
\hline & $\alpha(\times 100)$ & 67 & 66 & -1 & 0.755 \\
\hline \multirow{6}{*}{ Current job } & Age & 30.9 & 30.8 & 0 & 0.635 \\
\hline & Wage $(\$ / h r)$ & 23.29 & 18.54 & -20 & $0.000^{* * *}$ \\
\hline & Earnings ( $\$ / \mathrm{mo})$ & 4,190 & 2,768 & -34 & $0.000 * * *$ \\
\hline & Labor (hrs/wk) & 44 & 35 & -21 & $0.000^{* * *}$ \\
\hline & Labor (hrs/mo) & 180 & 151 & -16 & $0.000^{* * *}$ \\
\hline & $\alpha(\times 100)$ & 75 & 74 & -1 & 0.213 \\
\hline \multirow{4}{*}{ Experience } & Part time (wks) & 13 & 55 & 312 & $0.000^{* * *}$ \\
\hline & Full time (wks) & 327 & 271 & -17 & $0.000 * * *$ \\
\hline & Job spells & 9 & 9 & 2 & 0.497 \\
\hline & $N$ & 444 & 409 & -35 & -8 \\
\hline
\end{tabular}

We construct quintiles for $\alpha$ by assigning those with $\alpha \in[0.01,0.2]$ to the first quintile, $\alpha \in[0.21,0.4]$ to the second, and so forth. For each worker, we track their job changes, defined as any change in $\alpha$. We also track which $\alpha$ quintile the worker transitioned from. We find that women have fewer overall job changes than men (94 percent). Notably, women were 63 percent less likely to have held a past job in the first quintile, indicating that those jobs are predominantly held by men.

Tables 2 and 3 partition the sample into those with a college degree and those without, as education shows different trends in job choice and promotions. As one would expect, the college subsample holds higher AFQT scores, wages, $\alpha$, and rates of full-time work. Within the college subsample, men have on average slightly higher AFQT scores, by a tenth of a sample standard deviation, reflecting that college tends to be more selective for men than women, as 8.6 percent fewer men (3.5 percentage points) achieve a college degree. Men and women enter the labor market at similar ages and into jobs of similar complexity. Despite these similarities, women start with 11 percent lower wages on average. The gains in full-time employment associated with workers with a college degree accrue more to men than to women, as these women are 65 percent more likely than these men to work part-time, as opposed to 53 percent for the full sample. On average, women's monthly earnings are 66 percent of men's, 2 percent- 


\section{Table 3}

Sample Means and Differences, No College Degree

\begin{tabular}{|c|c|c|c|c|c|}
\hline & Variable & Men & Women & $\% \Delta$ & $p$-value \\
\hline \multirow{2}{*}{ Pre-labor market } & AFQT score (raw) & 50 & 50 & 0 & 0.927 \\
\hline & AFQT score (normal) & 0.4 & 0.4 & -2 & 0.927 \\
\hline \multirow{5}{*}{ First job } & Age & 19.3 & 19.4 & 1 & 0.808 \\
\hline & Wage $(\$ / \mathrm{hr})$ & 9 & 8 & -13 & $0.000^{* * *}$ \\
\hline & Earnings $(\$ / \mathrm{mo})$ & 1,498 & 1,098 & -27 & $0.000^{* * *}$ \\
\hline & Full time (\%) & 76 & 63 & -17 & $0.000 * * *$ \\
\hline & $\alpha(\times 100)$ & 40 & 66 & 65 & $0.000 * * *$ \\
\hline \multirow{6}{*}{ Current job } & Age & 27 & 27 & 0 & 0.647 \\
\hline & Wage $(\$ / h r)$ & 14 & 11 & -20 & $0.000 * * *$ \\
\hline & Earnings $(\$ / \mathrm{mo})$ & 2,392 & 1,620 & -32 & $0.000^{* * *}$ \\
\hline & Labor (hrs/wk) & 41 & 32.7 & -20 & $0.000 * * *$ \\
\hline & Labor (hrs/mo) & 173 & 146 & -15 & $0.000^{* * *}$ \\
\hline & $\alpha(\times 100)$ & 43 & 48 & 12 & $0.000 * * *$ \\
\hline \multirow{4}{*}{ Experience } & Part time (wks) & 28 & 69 & 144 & $0.000 * * *$ \\
\hline & Full time (wks) & 319 & 266 & -17 & $0.000 * * *$ \\
\hline & Job spells & 13.8 & 12.7 & -8 & $0.001^{* * *}$ \\
\hline & $N$ & 743 & 592 & -151 & -20 \\
\hline
\end{tabular}

age points less than the full sample. Women hourly wages are 20 percent lower than men's. On average, women work 16 percent fewer hours than men. Both men and women with a college degree accrue more full-time experience and less part-time experience than their counterparts without a college degree. Unlike in the full sample, in the college subsample, women have more job changes, although these changes are not statistically significant. As with the full sample, women hold fewer jobs in the first $\alpha$ quintile, more in the second, and about the same in the third and above.

Section 3 explores these statistics and their trends in more detail and discusses different hypotheses to explain them.

\section{GENDER GAPS OVER THE LIFE CYCLE}

Figure 1 shows the evolution of the average monthly earnings for men and women for the first 15 years after individuals enter the labor market. The gender gap is positive when men and women enter the labor market and increases with their labor market experience. Figure 1 shows that when we consider all workers, the gender gap increases almost 30 percent during the first 5 years of labor market experience, 22 percent in the following 5 years (from 
Figure 1

Mean Earnings by Gender and Career Age (All)

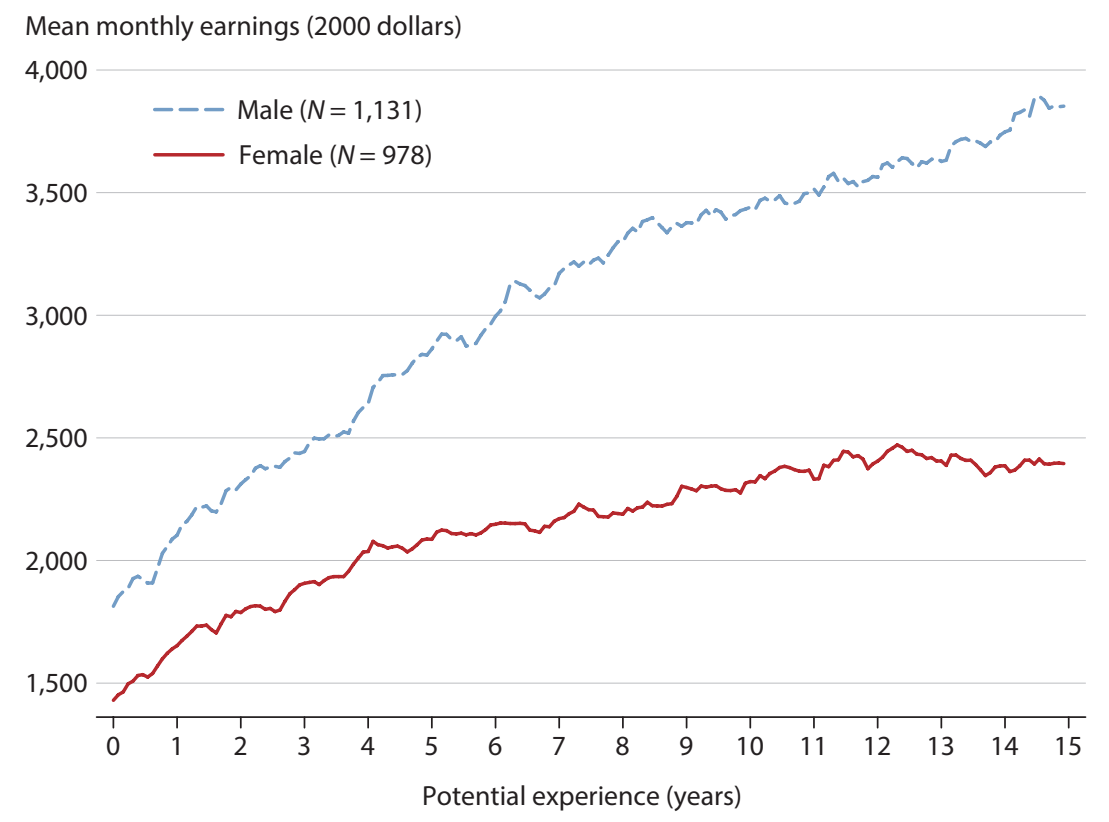

year 5 to year 10). The fact that the gender pay gaps increases over the life cycle is a welldocumented fact and can be partly attributed to an increasing difference in hours worked, labor market experience, the nature of jobs that men and women take, and promotion patterns. Note that while these factors can be attributed to differences in skills accumulated in the labor market in terms of human capital that workers accumulate with experience, those differences in human capital can be attributed to discrimination as well as preferences. It has been argued that women do more housework and take care of children more often than men and as a result work less and accumulate less human capital and work in jobs that provide more flexibility or demand fewer hours. However, this explanation does not rule out discrimination in the labor market, because the choices of how much time to spend on housework and child care may be partly driven by lower wages and lack of opportunity for promotions and jobs that require long hours but have high pay. While it is beyond the scope of this article to disentangle the fundamental factors driving the gaps, we proceed by documenting them and discuss explanations from the literature.

\subsection{Gender Gaps in Task Compexity and Hours Worked}

Two main factors that affect compensation are hours worked and the type of occupations and tasks men and women perform. Figures 2 to 4 document mean weekly hours worked by gender, career age, and education. Clearly, after the second year, the gap in hours worked grows substantially: 10 years after entry into the labor market, women with a college degree work 
Figure 2

Mean Weekly Hours by Gender and Career Age (All)

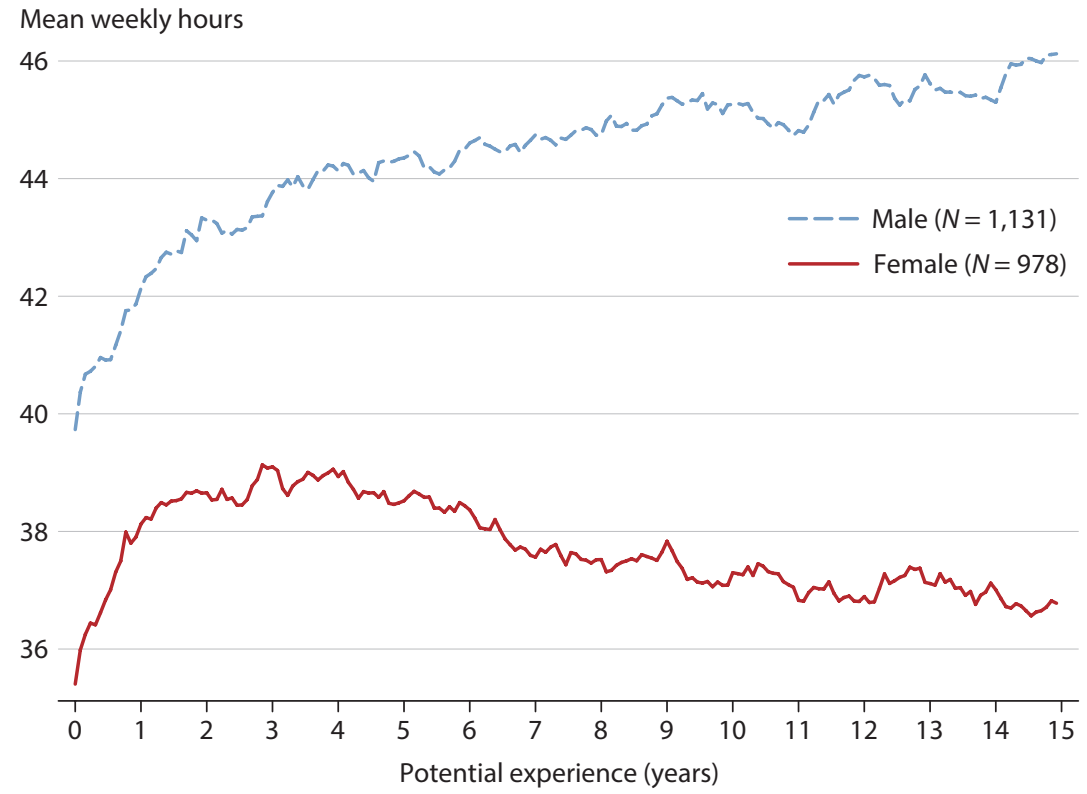

on average about 9 hours less than men; the gap increases slightly to 10.5 hours by year 15 . The same pattern is observed for workers without a college degree, although the gap is smaller (7 hours by year 10 and 9 hours by year 15). Typically, monthly pay depends on hours worked and, in addition, many high-paying jobs which pay high wages (even when computing the per hour wage rates) are not flexible and require working full time and many times long hours. It is unclear whether women choose to work fewer hours, especially during childbearing years, and whether the increases in the hours-worked gaps are due to women spending more time caring for children or to discrimination and lack of opportunities. Specializing in home production and choosing jobs with fewer hours may be related to discrimination: If women have lower potential earning than men with similar skills, education, and qualifications, it might lead to women spending more time at home and men spending more time in the workplace.

To further explore the evolution of the gaps, we document the evolution of gaps in occupational task assignments. As shown in Antonovics and Golan (2012), occupations with higher demand for complex tasks are associated with higher pay and for black and white men are an important source of the increase in the racial pay gap between them over the life cycle (see Golan et al., 2019, and Golan and Sanders, 2019). Figure 5 shows that while job complexity may explain this pay gap for men, women are on average assigned to jobs with higher task complexity. This is perhaps less surprising, as in our sample women are on average more educated than men. 


\section{Canon, Golan, Smith}

Figure 3

Mean Weekly Hours by Gender and Career Age (College)
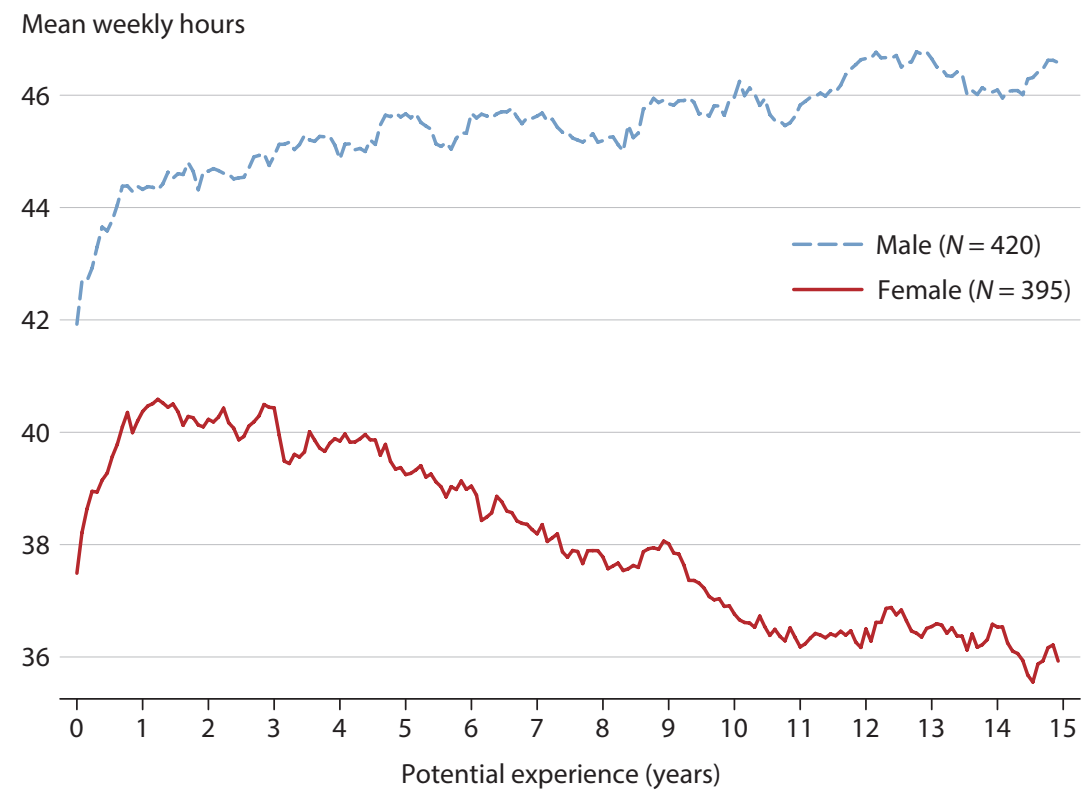

Figure 4

Mean Weekly Hours by Gender and Career Age (No College)

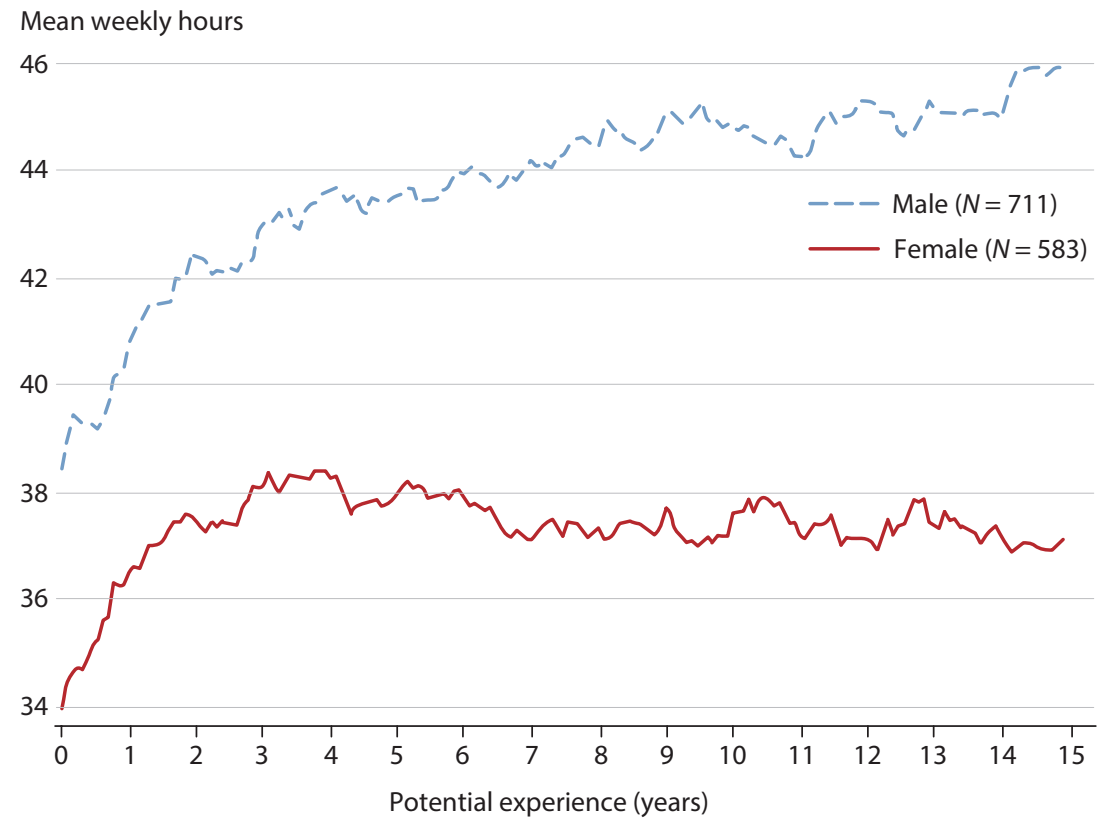


Figure 5

\section{Mean Job Complexity by Gender and Career Age (All)}

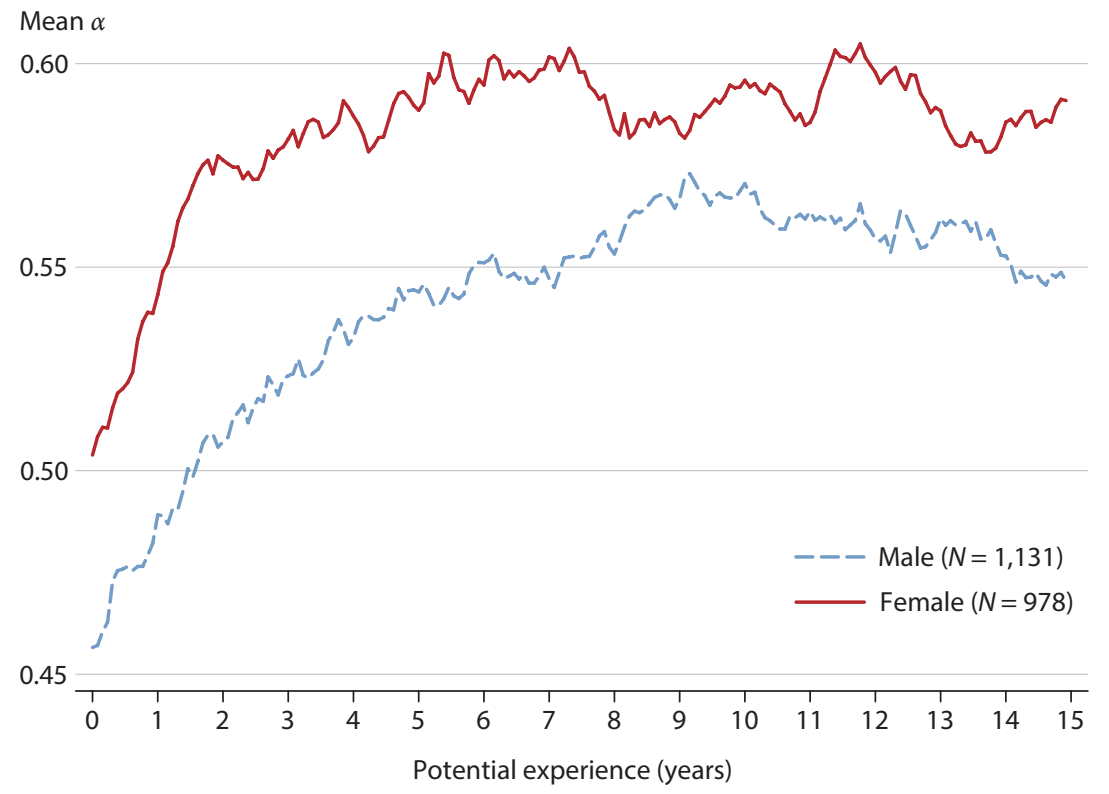

Figures 6 to 7 reveal differences in patterns by education group. Among workers without a college degree, women are assigned to jobs with higher task complexity and the gap remains as workers age, although it is larger up to year 8 than it is afterward. Therefore, this factor does not seem to play an important role in the increase in gender earnings gap patterns of workers without a college degree. College-educated women, however, are assigned to jobs with lower demand for complex tasks about 3 years after they enter the labor market and the gap is mostly larger in later years. While the average growth patterns are similar for men and women without a college degree, they differ for the those with a college degree: College-educated women are not on average employed in jobs with exceedingly increasing job complexity after the first year, while college-educated men are $-\alpha$ increases on average for men for the first 10 years. These patterns may reflect differences in promotions and occupational changes for college-educated men and women. 


\section{Canon, Golan, Smith}

Figure 6

Mean Job Complexity by Gender and Career Age (College)

Mean $\alpha$

0.80

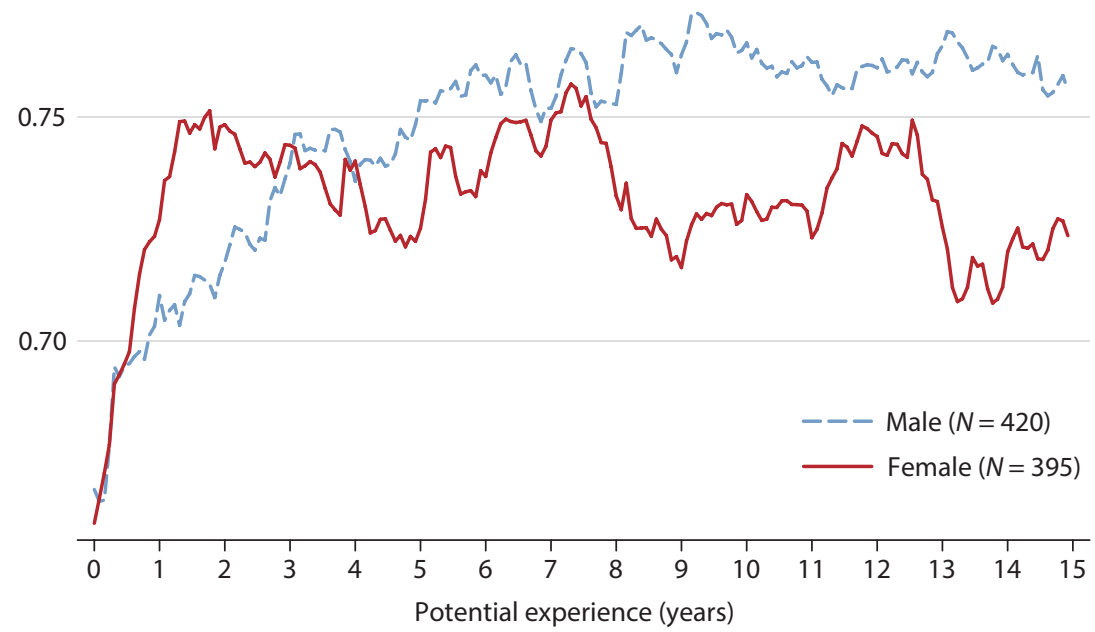

Figure 7

Mean Job Complexity by Gender and Career Age (No College)

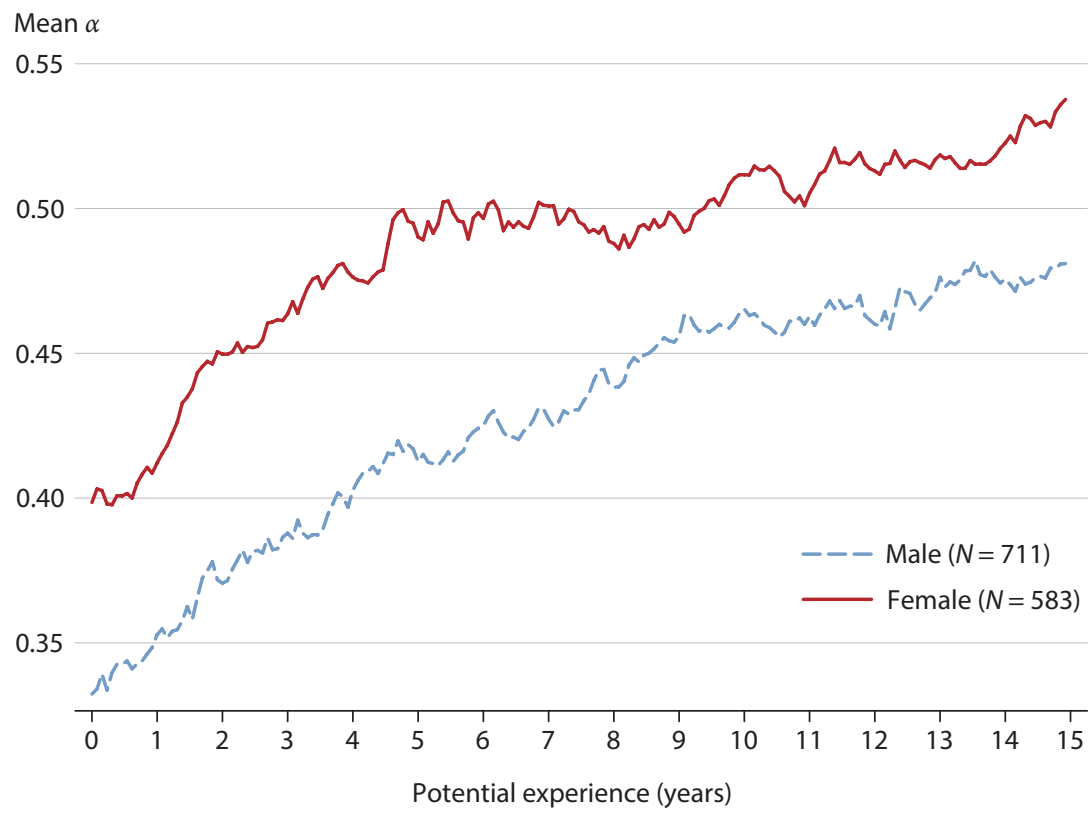




\subsection{Labor Market Experience}

Working longer hours is associated with higher pay; however, workers accumulate experience and human capital over time, which is reflected in the pay and productivity of workers currently working a similar number of hours but having different levels of experience. To explore this potential explanation, we look at those who work full time consistently, $\underline{11}$ as they earn more on average and more men than women work full time consistently. $\underline{12}$ We construct a subsample of workers who work full time consistently (labeled FTC) throughout the survey; precisely, we require they work full time in at least 80 percent of the sampled weeks. Figures 8 and 9 present the female-to-male mean monthly earnings ratio for the entire sample and for the FTC subsample by education group. The figures show that, for both workers with and workers without a college degree who work full time most of their careers, the gap increases by less than it does for the sample overall. This finding suggests that education and labor market experience (measured by hours of work each month) play an important role in explaining the gender pay gap.

There are several possible explanations for this pattern. The first is that the composition of the sample changes. For example, if skilled women (skill can be formal education and training but also innate ability, which is unobserved by the researchers) are more likely to work full time consistently, then the wage gap at a later age reflects the fact that we are comparing the wages of less-skilled women to those of men when they are both young, while we are comparing the wages of more-skilled women to those of men when they are both older. (The group of men working full-time continuously can be more stable because both more-skilled and less-skilled men are likely to work full time.) The second explanation is that, while men still work more hours than women, the gap in hours declines in this group; so, the increase in experience (and, therefore, labor market skills) of women who work full time continuously is larger than that of men. The third explanation is that the wage gap reflects discrimination: Discrimination of women who consistently work full time declines over time. We elaborate about the third explanation next.

Gayle and Golan (2011) develop a model in which men and women choose whether to work and hours and occupations. The authors show that statistical discrimination causes a large gender gap in human capital in the form of accrued experience, which is affected by both participation in the labor market and working long hours. Statistical discrimination arises from asymmetric information and employers' costs of hiring workers. These hiring costs might be higher in some occupations than others, due to higher training costs, for example. Workers know their own future labor supply, but employers do not. Hence, employers form a priori beliefs on a worker's labor market attachment and hours worked based on statistical averages. Women are statistically more likely to reduce hours or take maternity leave; when they do, employers must pay a replacement hiring cost. Therefore, it is more costly, on average, for employers to hire women than men. For that reason, in a competitive equilibrium, employers pass this cost on to women through lower wages or by not hiring them at all. In their data, Gayle and Golan (2011) find the gender gap closes by age 35 for men and women who work full time continuously. This fact is consistent with the hypothesis that the gender gap could be driven by statistical discrimination, that is, the average lower labor supply of women caused 


\section{Canon, Golan, Smith}

\section{Figure 8}

\section{Gender Earnings Gap by Career Age (College)}

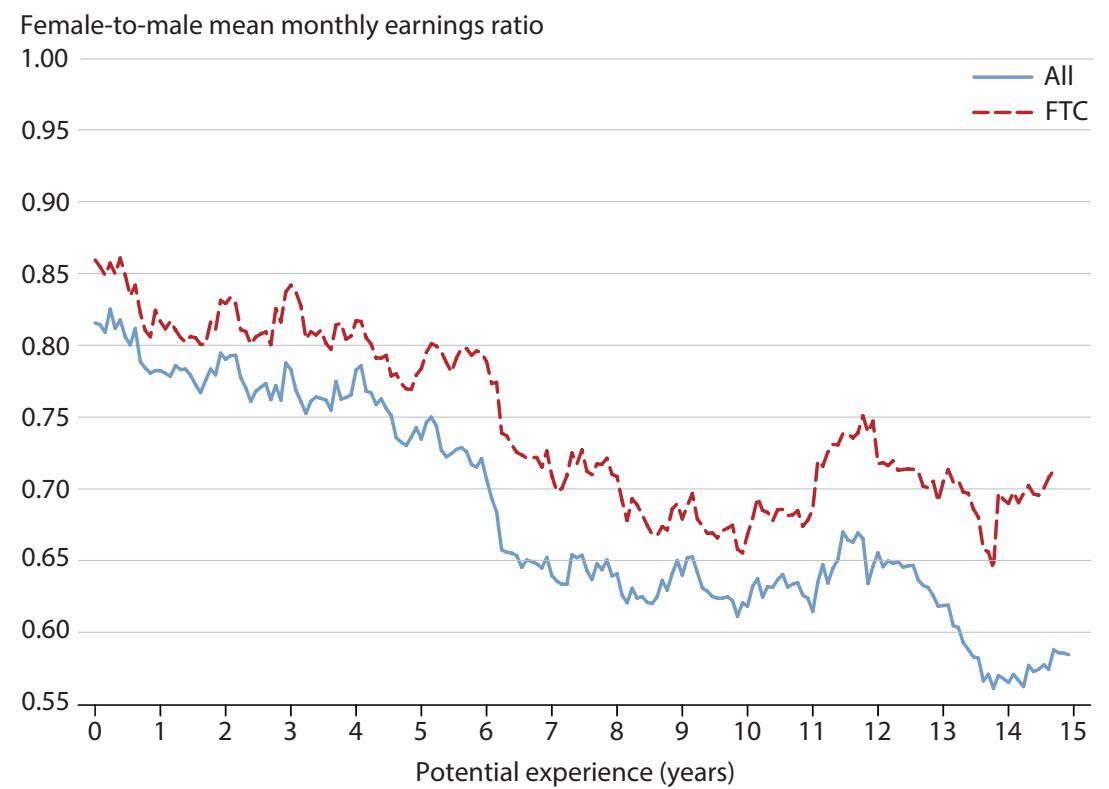

Figure 9

Gender Earnings Gap by Career Age (No College)

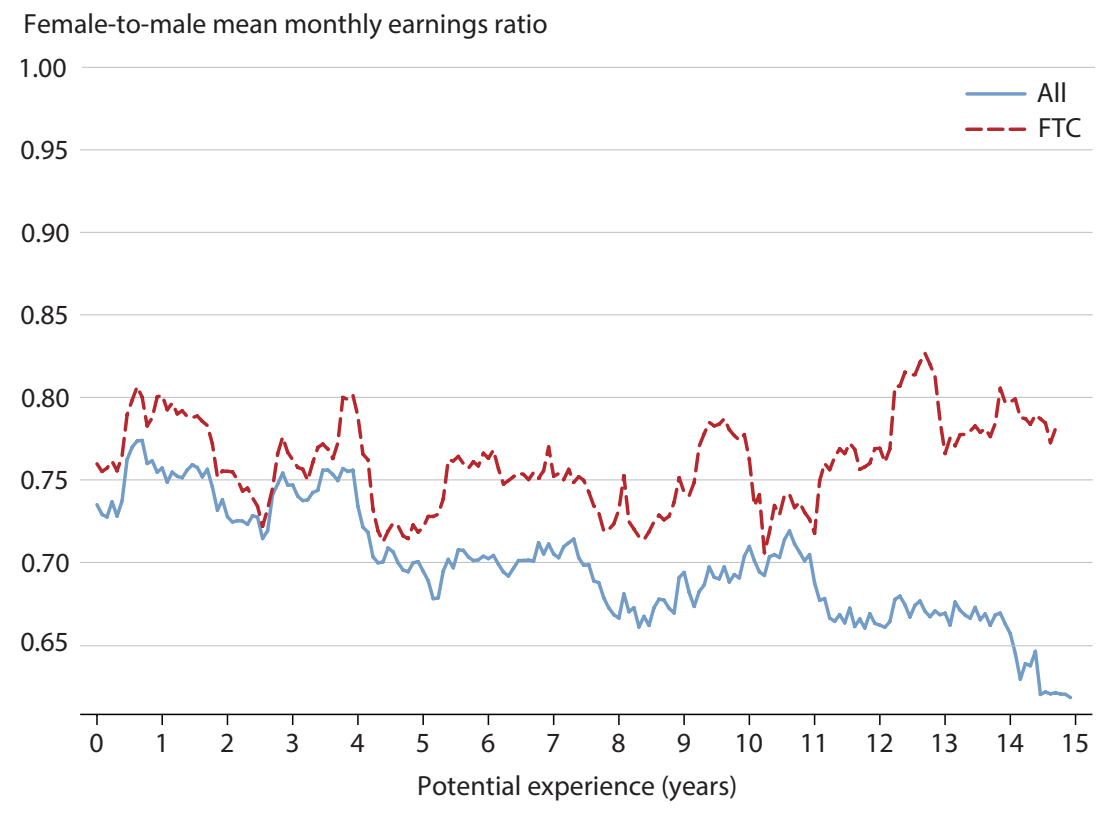


by family priorities that conflict with their careers. As a result, they receive lower wage offers, especially in occupations with large costs of hiring and high hours. However, women who consistently work high hours "signal" to employers that they are attached to the labor market. As a result, employers update their priors, reducing the pay gap for these women over time. $\frac{13}{3}$

\section{OBSERVABLE DIFFERENCES AND THE GENDER EARNINGS GAPS}

The patterns described above do not account for differences in composition between men and women, observable or not. To account for observable differences, we first regress earnings on observables, such as AFQT scores, and examine the correlation between the earning gaps and experience gained over the life cycle.

Table 4 presents the results for the earnings regressions for the full sample, for the subsample of workers with a college degree, and for the subsample of workers without a college degree. Column 1 shows that after controlling for the skills workers bring into the labor market there is still a gender gap in earnings. Column 3 of Table 4 adds years of part-time and fulltime labor market experience. Past history on hours worked reduces the gender earnings gap by 5 percent more for workers without a college degree, but it helps reduce the gap by 15 percent for workers with a college degree.

Controlling for current job complexity, Column 4 of Table 4 raises the gender gap 5 percent for workers with a college degree and by 15 percent for workers without a college degree, suggesting that men and women might sort differently into the two education groups. Column 5 adds controls for the worker's initial job, both for job complexity and earnings. The results are very heterogenous between the education groups. For both groups the gender gap decreases; but while initial job complexity has a positive effect on current earnings for workers without a college degree, it has a negligible effect for workers with a college degree. While controlling for observable characteristics that are endogenous, such as hours, experience, occupation, entry pay, and occupation, does not imply that there is no discrimination, we use the Blinder-Oaxaca decomposition to quantify below the importance of each of the observable differences.

\subsection{Quantifying the Role of Observed Differences}

We now present a succint illustration of the Blinder-Oaxaca decomposition. $\frac{14}{}$ For period $t$ and worker $i$, estimate separate male $(m)$ and female $(f)$ ordinary least-squares (OLS) wage regressions (the $i$ and $t$ subscripts are hidden for clarity):

$$
\begin{gathered}
Y_{m}=X_{m} B_{m}+u_{m} \\
Y_{f}=X_{f} B_{f}+u_{f},
\end{gathered}
$$

where $Y$ is wages, $X$ is a vector of explanatory variables, $B$ is a vector of coefficients, and $u$ is an error term.

Let $b_{m}$ and $b_{f}$ be the OLS estimates of $B_{m}$ and $B_{f}$. We denote mean values with an overbar. Then, since OLS with a constant term produces residuals with a zero mean, we have 
Table 4

Gender Pay Gap Regressions, Full Sample and by Schooling

\$ Per month

\begin{tabular}{|c|c|c|c|c|c|}
\hline & \\
\hline & (1) & $(2)$ & (3) & (4) & (5) \\
\hline \multicolumn{6}{|c|}{ A. Full sample } \\
\hline Male & $967(54)$ & $563(48)$ & $512(48)$ & $576(47)$ & $507(51)$ \\
\hline AFQT score (demeaned) & $308(29)$ & $294(27)$ & $287(26)$ & $211(25)$ & $167(23)$ \\
\hline College degree & $1,131(68)$ & $1,053(62)$ & $1,085(62)$ & $842(63)$ & $632(82)$ \\
\hline Labor (hrs/mo) & & $15.3(0.7)$ & $13.2(0.7)$ & $12.6(0.7)$ & $12.1(0.6)$ \\
\hline Experience, part time (yrs) & & & $28(12)$ & $25(12)$ & $47(12)$ \\
\hline Experience, full time (yrs) & & & $127(5)$ & $117(5)$ & $120(5)$ \\
\hline$\alpha$ & & & & $1,147(87)$ & $944(85)$ \\
\hline Entry pay $(\$ / m o)$ & & & & & $0.24(0.10)$ \\
\hline Entry $\alpha$ & & & & & $418(140)$ \\
\hline$N$ & 342,306 & 342,306 & 340,138 & 340,138 & 329,734 \\
\hline$R^{2}$ & 0.178 & 0.267 & 0.322 & 0.337 & 0.372 \\
\hline \multicolumn{6}{|c|}{ B. College } \\
\hline Male & $1,270(118)$ & $748(102)$ & $642(103)$ & $675(100)$ & $516(92)$ \\
\hline AFQT score (demeaned) & $636(81)$ & $614(73)$ & $602(73)$ & 495 (69) & $315(69)$ \\
\hline Labor (hrs/mo) & & $18.6(1.3)$ & $16.6(1.4)$ & $15.8(1.4)$ & $14.6(1.3)$ \\
\hline Experience, part time (yrs) & & & $38(26)$ & $55(26)$ & $88(23)$ \\
\hline Experience, full time (yrs) & & & $190(11)$ & $181(11)$ & $189(11)$ \\
\hline$\alpha$ & & & & $1,614(211)$ & $1,275(223)$ \\
\hline Entry pay $(\$ / m o)$ & & & & & $0.51(0.08)$ \\
\hline Entry $\alpha$ & & & & & $-36(241)$ \\
\hline$N$ & 128,546 & 128,546 & 128,228 & 128,228 & 123,276 \\
\hline$R^{2}$ & 0.095 & 0.180 & 0.257 & 0.273 & 0.329 \\
\hline \multicolumn{6}{|c|}{ C. No college } \\
\hline Male & $751(46)$ & $416(42)$ & $395(43)$ & $464(42)$ & $445(42)$ \\
\hline AFQT score & $190(26)$ & $180(24)$ & $175(24)$ & $117(23)$ & $107(22)$ \\
\hline Labor (hrs/mo) & & $13.2(0.7)$ & $11.4(0.7)$ & $10.9(0.7)$ & $10.7(0.6)$ \\
\hline Experience, part time (yrs) & & & $35(13)$ & $26(12)$ & $35(12)$ \\
\hline Experience, full time (yrs) & & & $91(4)$ & $83(4)$ & $83(4)$ \\
\hline$\alpha$ & & & & $895(75)$ & $824(69)$ \\
\hline Entry pay $(\$ / m o)$ & & & & & $0.12(0.04)$ \\
\hline Entry $\alpha$ & & & & & 325 (99) \\
\hline$N$ & 213,760 & 213,760 & 211,910 & 211,910 & 206,458 \\
\hline$R^{2}$ & 0.078 & 0.213 & 0.271 & 0.291 & 0.321 \\
\hline
\end{tabular}




$$
\bar{Y}_{m}-Y_{f}=b_{m} \bar{X}_{m}-b_{f} \bar{X}_{f}=b_{m}\left(\bar{X}_{m}-\bar{X}_{f}\right)+\bar{X}_{f}\left(b_{m}-b_{f}\right),
$$

where $b_{m}\left(\bar{X}_{m}-\bar{X}_{f}\right)$ is the impact of gender differences in the explanatory variables; $\left(\bar{X}_{m}-\bar{X}_{f}\right)$ is evaluated using the male coefficients; and $b_{m} \cdot \bar{X}_{f}\left(b_{m}-b_{f}\right)$ is the unexplained differential and corresponds to the average female residual from the male wage equation, which corresponds to an experiment where we take a woman, give her characteristics, and reward her according to the male "reward" system. We report the first component below.

Table 5 shows the results for each of the three samples (full, college, and no college) for different models. For each model, the top part of each panel presents the differentials of the predicted values of monthly earnings between the two groups (men and women) as well as the fraction of the differential that can be explained with the included regressors and which fraction remains unexplained. The bottom part of each panel decomposes the explained component by regressor. For each panel, the sum of all regressors equals the "Total explained" line.

Panel A, for the human capital basic model, shows that AFQT scores, a college degree, hours, and part-time and full-time experience explain 51 percent of the observed earnings gap for the full sample. Hours worked explains 41 percent of the gender gap, or 80 percent of the explained gap. A college degree has a negative contribution, reflecting that a higher fraction of women than men have a college degree. For the subsample with a college degree, the variables of the human capital basic model explain 59 percent of the observed earnings gap, 8 percent more than for the full sample, with AFQT being the main driver of that increase. For workers without a college degree, the results are closer to those for the full sample.

Panel B, for the current job conditions extended model, adds $\alpha$ of the current job. For all three samples, this model explains less than the model in Panel A. The contribution of $\alpha$ is negative for the full sample and the noncollege-educated subsample, reflecting that women without a college degree work more-complex jobs. Among college-educated workers, job complexity does not explain a significant fraction of the gender earnings gap.

Finally, Panel C, for the entry job conditions extended model, adds $\alpha$ and earnings of the first job. $\frac{15}{}$ By doing that, we account for additional unobserved heterogeneity of workers, that is, to the extent that pay reflects differences in initial skills and preferences. The results are very heterogenous across samples. For the full sample, characteristics of a worker's first job have a very significant effect in explaining the gender earnings gap, particularly so for initial earnings, which explains 10 percent of the total 52 percent explained. The negative contribution of current $\alpha$ falls, while entry $\alpha$ drives a part of the negative contribution. For the subsample of college-educated workers, first-job earnings explain 22 percent of the gender gap, increasing the fraction explained by all regressors to 67 percent. Allowing the model to account for first-job characteristics also allows part-time experience to have a negative contribution, reflecting the fact that more women in this group work fewer hours. As in Panel A, in Panel C, the decompositions for workers without a college degree are very similar to those for the full sample.

The results in this section suggest that human capital gained from work experience explains a large share of the gender pay gap at all education levels. 
Table 5

Decomposing the Gender Pay Gap, Full Sample and by Schooling

Effect of gender gap in explanatory variables

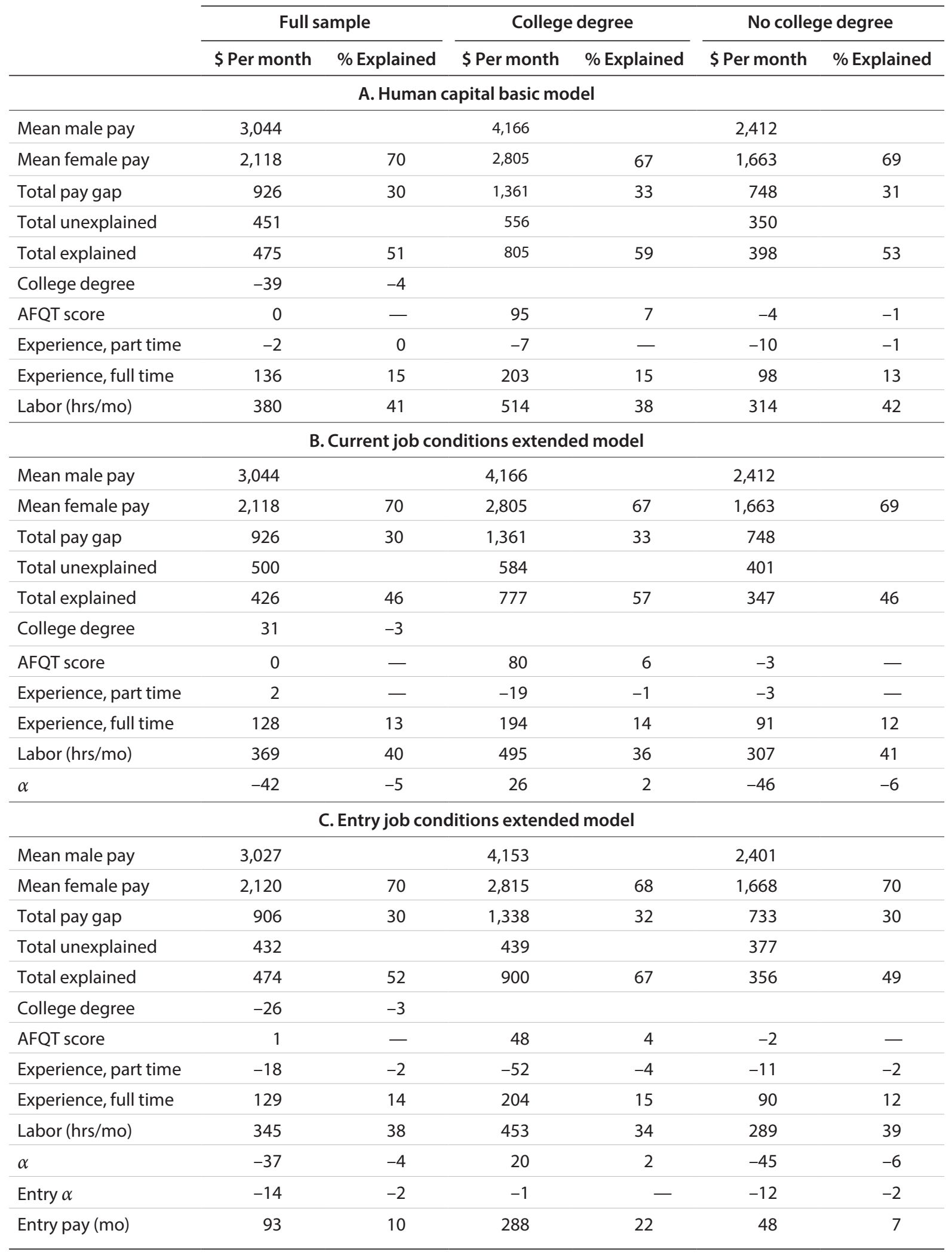


Table 6

Job and Wage Changes by Gender and Mover Category (AlI)

Weeks

\begin{tabular}{|c|c|c|c|c|c|c|c|c|}
\hline Men & $1-50$ & $51-100$ & $101-150$ & $151-200$ & $201-250$ & $251-300$ & $301-350$ & All \\
\hline \multicolumn{9}{|l|}{ Move up } \\
\hline$E[\Delta \alpha]$ & 0.25 & 0.25 & 0.25 & 0.23 & 0.24 & 0.22 & 0.23 & 0.24 \\
\hline$E[\Delta W]$ & 2.03 & 0.81 & 1.42 & 1.58 & 1.56 & 1.30 & 0.76 & 1.36 \\
\hline$E[\Delta H]$ & 1.32 & 2.24 & 2.24 & 0.56 & 1.18 & -0.42 & 0.55 & 1.19 \\
\hline$N$ & 463 & 495 & 449 & 414 & 373 & 352 & 341 & 2,887 \\
\hline \multicolumn{9}{|l|}{ Stayers } \\
\hline$E[\Delta W]$ & 0.00 & 0.00 & 0.00 & 0.00 & 0.00 & 0.00 & 0.00 & 0.00 \\
\hline$E[\Delta H]$ & 0.01 & 0.00 & 0.01 & 0.00 & 0.00 & 0.00 & 0.00 & 0.00 \\
\hline$N$ & 54,730 & 56,419 & 56,490 & 56,569 & 56,365 & 56,065 & 55,782 & 392,420 \\
\hline \multicolumn{9}{|c|}{ Move down } \\
\hline$E[\Delta \alpha]$ & -0.24 & -0.23 & -0.23 & -0.24 & -0.23 & -0.23 & -0.22 & -0.23 \\
\hline$E[\Delta W]$ & 1.51 & 0.63 & 0.70 & 1.01 & 1.02 & 1.19 & 1.30 & 1.03 \\
\hline$E[\Delta H]$ & 1.13 & -0.04 & -0.57 & 0.23 & -0.55 & -0.60 & -0.85 & -0.14 \\
\hline \multirow[t]{2}{*}{$N$} & 392 & 446 & 413 & 358 & 318 & 324 & 306 & 2,557 \\
\hline & \multicolumn{8}{|c|}{ Weeks } \\
\hline Women & $1-50$ & $51-100$ & $101-150$ & $151-200$ & $201-250$ & $251-300$ & $301-350$ & All \\
\hline \multicolumn{9}{|l|}{ Move up } \\
\hline$E[\Delta \alpha]$ & 0.24 & 0.23 & 0.24 & 0.22 & 0.23 & 0.22 & 0.23 & 0.23 \\
\hline$E[\Delta W]$ & 1.52 & 0.91 & 1.14 & 1.00 & 0.87 & 0.94 & 1.18 & 1.09 \\
\hline$E[\Delta H]$ & 3.04 & 1.40 & 1.38 & 1.01 & -0.12 & 1.09 & -0.06 & 1.20 \\
\hline$N$ & 369 & 388 & 345 & 322 & 290 & 274 & 276 & 2,264 \\
\hline \multicolumn{9}{|l|}{ Stayers } \\
\hline$E[\Delta W]$ & 0.00 & 0.00 & 0.00 & 0.01 & 0.00 & 0.00 & 0.00 & 0.00 \\
\hline$E[\Delta H]$ & 0.01 & 0.00 & 0.00 & 0.00 & 0.00 & 0.00 & -0.01 & 0.00 \\
\hline$N$ & 46,964 & 48,296 & 48,060 & 47,871 & 47,889 & 48,022 & 47,224 & 334,326 \\
\hline \multicolumn{9}{|c|}{ Move down } \\
\hline$E[\Delta \alpha]$ & -0.21 & -0.21 & -0.22 & -0.23 & -0.23 & -0.22 & -0.21 & -0.22 \\
\hline$E[\Delta W]$ & 0.27 & 1.10 & 1.09 & 0.28 & 1.03 & 0.45 & 1.61 & 0.82 \\
\hline$E[\Delta H]$ & 1.06 & -0.65 & -1.03 & -0.60 & -0.78 & -1.58 & -1.63 & -0.70 \\
\hline$N$ & 297 & 314 & 331 & 283 & 295 & 271 & 222 & 2,013 \\
\hline
\end{tabular}

NOTE: For men, the weekly probability of a move is 1.39 percent: 0.74 percent up and 0.65 percent down. For woman, the weekly probability of a move is 1.28 percent: 0.68 percent up and 0.60 percent down. A change is any $|\Delta \alpha| \geq 0.01$ persisting more than six weeks. Gaps in work are ignored. 


\section{Canon, Golan, Smith}

\section{Table 7}

Job and Wage Changes by Gender and Mover Category (College)

\begin{tabular}{|c|c|c|c|c|c|c|c|c|}
\hline \multirow[b]{2}{*}{ Men } & \multicolumn{8}{|c|}{ Weeks } \\
\hline & $1-50$ & $51-100$ & $101-150$ & $151-200$ & $201-250$ & $251-300$ & $301-350$ & All \\
\hline \multicolumn{9}{|l|}{ Move up } \\
\hline$E[\Delta \alpha]$ & 0.27 & 0.26 & 0.28 & 0.21 & 0.24 & 0.21 & 0.21 & 0.24 \\
\hline$E[\Delta W]$ & 3.44 & 1.48 & 2.48 & 3.05 & 1.99 & 3.37 & 2.24 & 2.59 \\
\hline$E[\Delta H]$ & 2.48 & 2.46 & 1.73 & 1.12 & 1.69 & -0.49 & 0.57 & 1.49 \\
\hline$N$ & 163 & 147 & 126 & 132 & 115 & 106 & 96 & 885 \\
\hline \multicolumn{9}{|l|}{ Stayers } \\
\hline$E[\Delta W]$ & 0.00 & 0.00 & 0.00 & 0.01 & 0.01 & 0.00 & -0.01 & 0.00 \\
\hline$E[\Delta H]$ & 0.00 & -0.01 & 0.00 & 0.00 & 0.00 & 0.00 & 0.00 & 0.00 \\
\hline$N$ & 20,571 & 21,180 & 21,240 & 21,272 & 20,864 & 20,653 & 20,402 & 146,182 \\
\hline \multicolumn{9}{|c|}{ Move down } \\
\hline$E[\Delta \alpha]$ & -0.24 & -0.23 & -0.23 & -0.23 & -0.21 & -0.23 & -0.23 & -0.23 \\
\hline$E[\Delta W]$ & 1.51 & 0.86 & -0.11 & 1.92 & 0.66 & 1.69 & 3.44 & 1.31 \\
\hline$E[\Delta H]$ & 2.65 & -0.62 & -0.48 & -0.79 & 0.63 & -1.48 & -1.84 & -0.24 \\
\hline$N$ & 112 & 159 & 124 & 109 & 92 & 95 & 86 & 777 \\
\hline
\end{tabular}

\begin{tabular}{|c|c|c|c|c|c|c|c|c|}
\hline \multirow[b]{2}{*}{ Women } & \multicolumn{8}{|c|}{ Weeks } \\
\hline & $1-50$ & $51-100$ & $101-150$ & $151-200$ & $201-250$ & $251-300$ & $301-350$ & All \\
\hline \multicolumn{9}{|l|}{ Move up } \\
\hline$E[\Delta \alpha]$ & 0.28 & 0.23 & 0.24 & 0.22 & 0.19 & 0.23 & 0.23 & 0.23 \\
\hline$E[\Delta W]$ & 2.21 & 1.50 & 1.36 & 1.95 & 1.53 & 2.04 & 1.61 & 1.77 \\
\hline$E[\Delta H]$ & 2.74 & 1.18 & 2.52 & -0.08 & -0.40 & 0.37 & -1.47 & 0.88 \\
\hline$N$ & 156 & 128 & 108 & 110 & 96 & 101 & 94 & 793 \\
\hline \multicolumn{9}{|l|}{ Stayers } \\
\hline$E[\Delta W]$ & 0.00 & 0.00 & 0.01 & 0.01 & 0.01 & -0.01 & 0.00 & 0.00 \\
\hline$E[\Delta H]$ & 0.01 & -0.01 & 0.00 & 0.00 & 0.00 & 0.00 & -0.01 & 0.00 \\
\hline$N$ & 19,067 & 19,820 & 19,612 & 19,363 & 19,364 & 19,483 & 18,875 & 135,584 \\
\hline \multicolumn{9}{|c|}{ Move down } \\
\hline$E[\Delta \alpha]$ & -0.21 & -0.24 & -0.25 & -0.24 & -0.23 & -0.19 & -0.22 & -0.23 \\
\hline$E[\Delta W]$ & -0.32 & 1.01 & 2.10 & -0.82 & 1.35 & 0.68 & 3.30 & 0.96 \\
\hline$E[\Delta H]$ & 0.83 & -1.75 & -2.78 & 0.37 & -1.52 & -1.77 & -0.74 & -1.05 \\
\hline$N$ & 102 & 110 & 110 & 111 & 109 & 84 & 77 & 703 \\
\hline
\end{tabular}

NOTE: For men, the weekly probability of a move is 1.14 percent: 0.61 percent up and 0.53 percent down. For woman, the weekly probability of a move is 1.06 percent: 0.55 percent up and 0.52 percent down. A change is any $|\Delta \alpha| \geq 0.01$ persisting more than six weeks. Gaps in work are ignored. 


\section{Table 8}

Job and Wage Changes by Gender and Mover Category (No College)

\begin{tabular}{|c|c|c|c|c|c|c|c|c|}
\hline \multirow[b]{2}{*}{ Men } & \multicolumn{8}{|c|}{ Weeks } \\
\hline & $1-50$ & $51-100$ & $101-150$ & $151-200$ & $201-250$ & $251-300$ & $301-350$ & All \\
\hline \multicolumn{9}{|l|}{ Move up } \\
\hline$E[\Delta \alpha]$ & 0.25 & 0.25 & 0.23 & 0.23 & 0.24 & 0.22 & 0.24 & 0.24 \\
\hline$E[\Delta W]$ & 1.26 & 0.52 & 1.01 & 0.89 & 1.38 & 0.40 & 0.18 & 0.82 \\
\hline$E[\Delta H]$ & 0.67 & 2.14 & 2.44 & 0.30 & 0.95 & -0.39 & 0.55 & 1.05 \\
\hline$N$ & 300 & 348 & 323 & 282 & 258 & 246 & 245 & 2,002 \\
\hline \multicolumn{9}{|l|}{ Stayers } \\
\hline$E[\Delta W]$ & -0.01 & 0.00 & 0.00 & 0.00 & 0.00 & 0.00 & 0.00 & 0.00 \\
\hline$E[\Delta H]$ & 0.02 & 0.00 & 0.01 & 0.00 & 0.01 & 0.01 & 0.00 & 0.01 \\
\hline$N$ & 34,159 & 35,239 & 35,250 & 35,297 & 35,501 & 35,412 & 35,380 & 246,238 \\
\hline \multicolumn{9}{|c|}{ Move down } \\
\hline$E[\Delta \alpha]$ & -0.23 & -0.23 & -0.23 & -0.24 & -0.24 & -0.23 & -0.22 & -0.23 \\
\hline$E[\Delta W]$ & 1.51 & 0.50 & 1.05 & 0.61 & 1.17 & 0.98 & 0.47 & 0.91 \\
\hline$E[\Delta H]$ & 0.51 & 0.28 & -0.60 & 0.67 & -1.06 & -0.22 & -0.43 & -0.09 \\
\hline$N$ & 280 & 287 & 289 & 249 & 226 & 229 & 220 & 1,780 \\
\hline
\end{tabular}

\begin{tabular}{|c|c|c|c|c|c|c|c|c|}
\hline \multirow[b]{2}{*}{ Women } & \multicolumn{8}{|c|}{ Weeks } \\
\hline & $1-50$ & $51-100$ & $101-150$ & $151-200$ & $201-250$ & $251-300$ & $301-350$ & All \\
\hline \multicolumn{9}{|l|}{ Move up } \\
\hline$E[\Delta \alpha]$ & 0.21 & 0.23 & 0.24 & 0.23 & 0.25 & 0.22 & 0.23 & 0.23 \\
\hline$E[\Delta W]$ & 1.01 & 0.62 & 1.04 & 0.50 & 0.55 & 0.30 & 0.95 & 0.72 \\
\hline$E[\Delta H]$ & 3.25 & 1.51 & 0.88 & 1.58 & 0.01 & 1.51 & 0.68 & 1.37 \\
\hline$N$ & 213 & 260 & 237 & 212 & 194 & 173 & 182 & 1,471 \\
\hline \multicolumn{9}{|l|}{ Stayers } \\
\hline$E[\Delta W]$ & 0.00 & -0.01 & 0.00 & 0.00 & -0.01 & 0.01 & 0.00 & 0.00 \\
\hline$E[\Delta H]$ & 0.01 & 0.00 & 0.00 & 0.00 & 0.00 & 0.01 & 0.00 & 0.00 \\
\hline$N$ & 27,897 & 28,476 & 28,448 & 28,508 & 28,525 & 28,539 & 28,349 & 198,742 \\
\hline \multicolumn{9}{|c|}{ Move down } \\
\hline$E[\Delta \alpha]$ & -0.21 & -0.20 & -0.20 & -0.23 & -0.23 & -0.24 & -0.21 & -0.21 \\
\hline$E[\Delta W]$ & 0.58 & 1.15 & 0.60 & 0.99 & 0.84 & 0.35 & 0.71 & 0.74 \\
\hline$E[\Delta H]$ & 1.19 & -0.04 & -0.16 & -1.23 & -0.35 & -1.49 & -2.12 & -0.52 \\
\hline$N$ & 195 & 204 & 221 & 172 & 186 & 187 & 145 & 1,310 \\
\hline
\end{tabular}

NOTE: For men, the weekly probability of a move is 1.54 percent: 0.81 percent up and 0.72 percent down. For woman, the weekly probability of a move is 1.40 percent: 0.74 percent up and 0.66 percent down. A change is any $|\Delta \alpha| \geq 0.01$ persisting more than six weeks. Gaps in work are ignored. 


\section{Canon, Golan, Smith}

Some potential causes for the gender pay gap could be first that workers accumulate skills and learn while working. Because men work on average more hours, they accumulate more skills. It could also be that workers are endowed with skills but workers are uncertain about the skills they have. Workers learn about their skills over time; that is, jobs are experienced goods (as suggested by Antonovics and Golan, 2012) that help workers learn about themselves and sort into jobs for which they are better matched. We explore next the role of learning through job turnover.

\section{JOB CHOICE AND TURNOVER}

As shown above, hours worked and past hours are important factors determining the gender pay gap, while occupational changes might be an important factor in understanding the gender pay gap for college-educated workers. On average, job transitions are associated with wage growth over the life cycle. Specifically, Antonovics and Golan (2012) find that for men who change occupations, on average, wages increase. This pattern holds for workers who move up in terms of job complexity as well as for workers who move down, although the mean increase in wages associated with turnover is smaller for the latter group. There are several explanations consistent with these patterns. An important factor is that workers are sorted into matches that better fit their skills over time, which can be for several reasons. One is learning by doing (e.g., Jovanovic and Nyarko, 1970), through which workers learn how to perform tasks and accordingly move up the job ladder, causing wages to increase over time. A second is search frictions: Workers may not always find the jobs that best suit their qualifications initially, but over time they search and move when they find better matches. Another explanation is that workers do not always know which type of job matches their skills best and then learn this through experience (Jovanovic, 1979; Miller, 1984; and Antonovics and Golan, 2012, among others). In this article, we separately document the patterns of occupational changes and wage changes for men and women. Tables 6 to 8 document the patterns by weeks of employment. There are job changes during the 350 weeks but more occur in the first 150 weeks. Workers who move up have larger wage gains than those who move down, but on average the hourly wage changes are positive. Men, on average, have about 25 percent larger hourly wage gains when changing occupations. For them, moving up is associated with an additional 1.2 hours a week and moving down is associated with a reduction in hours, but the average changes are small. We find similar patterns for women, who on average move less often and for smaller raises.

Wage changes are much smaller (less than $\$ 1$ per hour) among workers without a college degree. While women without a college degree have a smaller wage increase when they move than women with a college degree, the increase in their gender pay gap is less than that for women with a college degree, as both a fraction and an amount. For workers without a college degree who move up, on average, men work 1.1 more hours per week and women 1.4 hours per week; the gender gap in hours from a promotion is the reverse of that for the college group. Of workers who move down, on average, men work about the same hours and women 0.5 hours less. 


\section{Table 9}

Average Marginal Effects on Turnover (College)

\begin{tabular}{|c|c|c|c|c|c|c|}
\hline & (1) & (2) & (3) & (4) & (5) & (6) \\
\hline Male & $\begin{array}{l}0.0218 \\
(1.71)\end{array}$ & $\begin{array}{l}0.0238 \\
(1.83)\end{array}$ & $\begin{array}{l}0.0385^{* *} \\
(2.92)\end{array}$ & $\begin{array}{l}0.0381^{* * *} \\
(3.07)\end{array}$ & $\begin{array}{l}0.0413^{* *} \\
(3.27)\end{array}$ & $\begin{array}{l}0.0359^{* *} \\
(3.01)\end{array}$ \\
\hline Age & $\begin{array}{l}-0.0278^{* * *} \\
(-25.51)\end{array}$ & $\begin{array}{l}-0.0280^{* * * *} \\
(-25.31)\end{array}$ & $\begin{array}{l}-0.0250^{* * *} \\
(-22.56)\end{array}$ & $\begin{array}{l}-0.0303^{* * *} \\
(-21.62)\end{array}$ & $\begin{array}{l}-0.0306^{* * *} \\
(-21.89)\end{array}$ & $\begin{array}{l}-0.0194^{* * * *} \\
(-8.78)\end{array}$ \\
\hline AFQT score & & $\begin{array}{l}-0.0127 \\
(-1.48)\end{array}$ & $\begin{array}{l}0.0117 \\
(1.41)\end{array}$ & $\begin{array}{l}0.0136 \\
(1.74)\end{array}$ & $\begin{array}{l}0.0121 \\
(1.55)\end{array}$ & $\begin{array}{l}0.0138 \\
(1.87)\end{array}$ \\
\hline Hours (yr) & & & $\begin{array}{l}-0.0632^{* *} \\
(-2.94)\end{array}$ & $\begin{array}{l}-0.0541 * * \\
(-2.58)\end{array}$ & $\begin{array}{l}-0.0546^{* *} \\
(-2.60)\end{array}$ & $\begin{array}{l}-0.0631^{* *} \\
(-2.90)\end{array}$ \\
\hline$\alpha$ & & & $\begin{array}{l}-0.347^{* * *} \\
(-13.92)\end{array}$ & $\begin{array}{l}-0.324^{* * *} \\
(-13.27)\end{array}$ & $\begin{array}{l}-0.339 * * * \\
(-12.82)\end{array}$ & $\begin{array}{l}-0.341^{* * *} \\
(-13.18)\end{array}$ \\
\hline Job changes & & & & $\begin{array}{l}0.00945^{* * * *} \\
(5.84)\end{array}$ & & \\
\hline Job changes (1) & & & & & $\begin{array}{l}-0.00752 \\
(-0.70)\end{array}$ & $\begin{array}{l}-0.00485 \\
(-0.46)\end{array}$ \\
\hline Job changes (2) & & & & & $\begin{array}{l}0.00653 \\
(0.92)\end{array}$ & $\begin{array}{l}0.0125 \\
(1.72)\end{array}$ \\
\hline Job changes (3) & & & & & $\begin{array}{l}0.00641 \\
(1.29)\end{array}$ & $\begin{array}{l}0.0134^{* *} \\
(2.62)\end{array}$ \\
\hline Job changes (4) & & & & & $\begin{array}{l}0.0158^{* * *} \\
(4.45)\end{array}$ & $\begin{array}{l}0.0242^{* * * *} \\
(6.59)\end{array}$ \\
\hline Job changes (5) & & & & & $\begin{array}{l}0.0103^{* * *} \\
(3.85)\end{array}$ & $\begin{array}{l}0.0138^{* * *} \\
(5.14)\end{array}$ \\
\hline Part-time experience & & & & & & $\begin{array}{l}-0.0303^{* * *} \\
(-5.25)\end{array}$ \\
\hline Full-time experience & & & & & & $\begin{array}{l}-0.0180^{* * * *} \\
(-6.33)\end{array}$ \\
\hline$N$ & 11,488 & 11,206 & 11,206 & 11,206 & 11,206 & 1,155 \\
\hline
\end{tabular}

NOTE: $t$-statistics are in parentheses. ${ }^{*} p<0.05,{ }^{* *} p<0.01,{ }^{* * *} p<0.001$.

Table 9 shows a logit regression of the probability of a job change $\frac{16}{6}$ next year. Columns 1 and 2 show that men are more likely than women to change jobs, all else equal, for both education groups. To control for job characteristics, we add job complexity to the regression as well as hours, since hours and $\alpha$ may imply different types of jobs. Columns 3 to 6 show that job characteristics increase the gender gap in the probability of a job change. Column 3 shows that conditional on $\alpha$ and hours, college-educated men are 3.9 percentage points likelier than college-educated women to change jobs. $\frac{17}{}$

Table 10 shows the pattern also holds for workers without a college degree. Column 3 shows conditional on job complexity and hours, noncollege-educated men are 4.8 percentage point more likely than noncollege-educated woman to change jobs. Tables 11 to 12 repeat the effect for promotions $\frac{18}{\underline{1}}$ since promotions bring greater wage gains on average. Column 1 of 
Canon, Golan, Smith

Table 10

Average Marginal Effects on Turnover (No College)

\begin{tabular}{|c|c|c|c|c|c|c|}
\hline & (1) & $(2)$ & (3) & (4) & (5) & (6) \\
\hline Male & $\begin{array}{l}0.0345^{* * *} \\
(3.52)\end{array}$ & $\begin{array}{l}0.0349 * * * \\
(3.50)\end{array}$ & $\begin{array}{l}0.0479 * * * \\
(4.54)\end{array}$ & $\begin{array}{l}0.0410^{* * *} \\
(4.13)\end{array}$ & $\begin{array}{l}0.0431^{* * *} \\
(4.19)\end{array}$ & $\begin{array}{l}0.0360^{* * *} \\
(3.62)\end{array}$ \\
\hline Age & $\begin{array}{l}-0.0215^{* * *} \\
(-25.29)\end{array}$ & $\begin{array}{l}-0.0222^{* * *} \\
(-25.94)\end{array}$ & $\begin{array}{l}-0.0209^{* * *} \\
(-23.87)\end{array}$ & $\begin{array}{l}-0.0277^{* * *} \\
(-23.57)\end{array}$ & $\begin{array}{l}-0.0288^{* * *} \\
(-23.38)\end{array}$ & $\begin{array}{l}-0.0185^{* * *} \\
(-9.62)\end{array}$ \\
\hline AFQT score & & $\begin{array}{l}-0.00996 \\
(-1.84)\end{array}$ & $\begin{array}{l}-0.00438 \\
(-0.80)\end{array}$ & $\begin{array}{l}-0.00359 \\
(-0.70)\end{array}$ & $\begin{array}{l}-0.00480 \\
(-0.93)\end{array}$ & $\begin{array}{l}-0.00334 \\
(-0.67)\end{array}$ \\
\hline Hours (yr) & & & $\begin{array}{l}-0.112^{* * *} \\
(-7.02)\end{array}$ & $\begin{array}{l}-0.104^{* * *} \\
(-6.72)\end{array}$ & $\begin{array}{l}-0.110^{* * *} \\
(-7.07)\end{array}$ & $\begin{array}{l}-0.117^{* * *} \\
(-7.34)\end{array}$ \\
\hline$\alpha$ & & & $\begin{array}{l}-0.0672^{* * *} \\
(-3.64)\end{array}$ & $\begin{array}{l}-0.0604^{* * *} \\
(-3.39)\end{array}$ & $\begin{array}{l}-0.0701^{* * *} \\
(-3.79)\end{array}$ & $\begin{array}{l}-0.0649 * * * \\
(-3.55)\end{array}$ \\
\hline Job changes & & & & $\begin{array}{l}0.00863^{* * *} \\
(8.70)\end{array}$ & & \\
\hline Job changes (1) & & & & & $\begin{array}{l}0.0101^{* * *} \\
(3.45)\end{array}$ & $\begin{array}{l}0.0155^{* * *} \\
(5.12)\end{array}$ \\
\hline Job changes (2) & & & & & $\begin{array}{l}0.0132^{* * *} \\
(4.46)\end{array}$ & $\begin{array}{l}0.0206^{* * *} \\
(6.73)\end{array}$ \\
\hline Job changes (3) & & & & & $\begin{array}{l}0.0146^{* * *} \\
(4.53)\end{array}$ & $\begin{array}{l}0.0216^{* * *} \\
(6.38)\end{array}$ \\
\hline Job changes (4) & & & & & $\begin{array}{l}0.0161^{* * *} \\
(5.11)\end{array}$ & $\begin{array}{l}0.0223^{* * * *} \\
(6.69)\end{array}$ \\
\hline Job changes (5) & & & & & $\begin{array}{l}0.00158 \\
(0.60)\end{array}$ & $\begin{array}{l}-0.00413 \\
(-1.48)\end{array}$ \\
\hline Part-time experience & & & & & & $\begin{array}{l}-0.0272^{* * * *} \\
(-6.19)\end{array}$ \\
\hline Full-time experience & & & & & & $\begin{array}{l}-0.0151^{* * * *} \\
(-6.09)\end{array}$ \\
\hline$N$ & 19,880 & 19,106 & 19,106 & 19,106 & 19,106 & 18,883 \\
\hline
\end{tabular}

NOTE: $t$-statistics are in parentheses. ${ }^{*} p<0.05,{ }^{* *} p<0.01,{ }^{* * *} p<0.001$.

Table 13 shows that college-educated men have a 2 percentage point higher probability of a promotion, but Column 3 shows the gap is smaller and insignificant when we control for $\alpha$ and hours. Column 1 of Table 14 shows that noncollege-educated men have no significantly greater probability of a promotion than women, but Column 3 shows that conditional on $\alpha$ and hours, noncollege-educated men are 3 percentage points less likely than noncollege-educated women to be promoted. Thus, the higher turnover probability for men without a college degree is due to changes to a lower $\alpha$, as seen in Column 3 of Table 14. As discussed above, these patterns are consistent with a theory of learning and sorting, where workers sort into better-matching jobs; thus, men may be more likely to change jobs and find a better match on average.

The question of why women are less likely to change jobs has several possible explanations. One explanation, consistent with learning and sorting theories, is that because women spend 


\section{Table 11}

Average Marginal Effects on Promotion (College)

\begin{tabular}{|c|c|c|c|c|c|c|}
\hline & (1) & (2) & (3) & (4) & (5) & (6) \\
\hline Male & $\begin{array}{l}0.0223^{* *} \\
(2.61)\end{array}$ & $\begin{array}{l}0.0212^{*} \\
(2.45)\end{array}$ & $\begin{array}{l}0.00890 \\
(0.88)\end{array}$ & $\begin{array}{l}0.00890 \\
(0.88)\end{array}$ & $\begin{array}{l}0.0172 \\
(1.75)\end{array}$ & $\begin{array}{l}0.0127 \\
(1.34)\end{array}$ \\
\hline Age & $\begin{array}{l}-0.0151^{* * *} \\
(-18.90)\end{array}$ & $\begin{array}{l}-0.0151^{* * *} \\
(-18.68)\end{array}$ & $\begin{array}{l}-0.00969 * * * \\
(-12.08)\end{array}$ & $\begin{array}{l}-0.00978^{* * *} \\
(-7.69)\end{array}$ & $\begin{array}{l}-0.0101^{* * * *} \\
(-8.07)\end{array}$ & $\begin{array}{l}-0.00361^{*} \\
(-2.04)\end{array}$ \\
\hline AFQT score & & $\begin{array}{l}0.00551 \\
(0.93)\end{array}$ & $\begin{array}{l}0.0415^{* * *} \\
(5.96)\end{array}$ & $\begin{array}{l}0.0415^{* * *} \\
(5.97)\end{array}$ & $\begin{array}{l}0.0316^{* * *} \\
(4.93)\end{array}$ & $\begin{array}{l}0.0327^{* * *} \\
(5.26)\end{array}$ \\
\hline Hours (yr) & & & $\begin{array}{l}0.0189 \\
(1.17)\end{array}$ & $\begin{array}{l}0.0190 \\
(1.17)\end{array}$ & $\begin{array}{l}0.0260 \\
(1.65)\end{array}$ & $\begin{array}{l}0.0177 \\
(1.10)\end{array}$ \\
\hline$\alpha$ & & & $\begin{array}{l}-0.557^{* * *} \\
(-24.57)\end{array}$ & $\begin{array}{l}-0.557^{* * * *} \\
(-23.74)\end{array}$ & $\begin{array}{l}-0.622^{* * *} \\
(-26.11)\end{array}$ & $\begin{array}{l}-0.617^{* * *} \\
(-26.00)\end{array}$ \\
\hline Job changes & & & & $\begin{array}{l}0.000155 \\
(0.10)\end{array}$ & & \\
\hline Job changes (1) & & & & & $\begin{array}{l}-0.0400^{* * * *} \\
(-4.64)\end{array}$ & $\begin{array}{l}-0.0377^{* * *} \\
(-4.53)\end{array}$ \\
\hline Job changes (2) & & & & & $\begin{array}{l}-0.0195^{* * * *} \\
(-3.44)\end{array}$ & $\begin{array}{l}-0.0157^{* *} \\
(-2.67)\end{array}$ \\
\hline Job changes (3) & & & & & $\begin{array}{l}-0.00979^{*} \\
(-2.53)\end{array}$ & $\begin{array}{l}-0.00589 \\
(-1.47)\end{array}$ \\
\hline Job changes (4) & & & & & $\begin{array}{l}0.000850 \\
(0.27)\end{array}$ & $\begin{array}{l}0.00532 \\
(1.64)\end{array}$ \\
\hline Job changes (5) & & & & & $\begin{array}{l}0.0135^{* * *} \\
(6.36)\end{array}$ & $\begin{array}{l}0.0147^{* * *} \\
(6.76)\end{array}$ \\
\hline Part-time experience & & & & & & $\begin{array}{l}-0.0197^{* * *} \\
(-4.31)\end{array}$ \\
\hline Full-time experience & & & & & & $\begin{array}{l}-0.00996 * * * \\
(-4.50)\end{array}$ \\
\hline$N$ & 9,984 & 9,753 & 9,753 & 9,753 & 9,753 & 9,702 \\
\hline
\end{tabular}

NOTE: $t$-statistics are in parentheses. ${ }^{*} p<0.05,{ }^{* *} p<0.01,{ }^{* * *} p<0.001$.

less time working on average they acquire less information about their own skills and therefore are less likely to change jobs for a better match; this explanation may imply that women are less likely to be in jobs that are a good match for their skills. It is also possible, however, that women are less likely to change jobs for other reasons, such as a lower propensity to move to jobs that require a location change due to family considerations (see Gemici, 2011, and Flabbi and Mabli, 2018, among others). Another possibility is that women are less likely to receive offers due to discrimination (see Flabbi, 2010, for a search model with gender discrimination). 


\section{Canon, Golan, Smith}

Table 12

Average Marginal Effects on Promotion (No College)

\begin{tabular}{|c|c|c|c|c|c|c|}
\hline & (1) & $(2)$ & (3) & (4) & (5) & (6) \\
\hline Male & $\begin{array}{l}0.0131 \\
(2.35)\end{array}$ & $\begin{array}{l}0.0125 \\
(2.19)\end{array}$ & $\begin{array}{l}-0.0302^{* *} \\
(-3.77)\end{array}$ & $\begin{array}{l}-0.0336^{* *} \\
(-4.27)\end{array}$ & $\begin{array}{l}-0.0152 \\
(-1.99)\end{array}$ & $\begin{array}{l}-0.0166 \\
(-2.14)\end{array}$ \\
\hline Age & $\begin{array}{l}-0.0108^{* *} \\
(-19.33)\end{array}$ & $\begin{array}{l}-0.0110^{* *} \\
(-19.37)\end{array}$ & $\begin{array}{l}-0.00629 * * \\
(-10.24)\end{array}$ & $\begin{array}{l}-0.00935^{* *} \\
(-9.96)\end{array}$ & $\begin{array}{l}-0.0101^{* *} \\
(-10.35)\end{array}$ & $\begin{array}{l}-0.00772^{* *} \\
(-4.76)\end{array}$ \\
\hline AFQT score & & $\begin{array}{l}0.000579 \\
(0.19)\end{array}$ & $\begin{array}{l}0.0339 * * \\
(8.32)\end{array}$ & $\begin{array}{l}0.0338^{* *} \\
(8.45)\end{array}$ & $\begin{array}{l}0.0267^{* *} \\
(7.03)\end{array}$ & $\begin{array}{l}0.0274^{* *} \\
(7.18)\end{array}$ \\
\hline Hours (yr) & & & $\begin{array}{l}-0.000871 \\
(-0.07)\end{array}$ & $\begin{array}{l}0.00300 \\
(0.25)\end{array}$ & $\begin{array}{l}0.00155 \\
(0.12)\end{array}$ & $\begin{array}{l}-0.00159 \\
(-0.12)\end{array}$ \\
\hline$\alpha$ & & & $\begin{array}{l}-0.581^{* *} \\
(-36.89)\end{array}$ & $\begin{array}{l}-0.578^{* *} \\
(-37.32)\end{array}$ & $\begin{array}{l}-0.658^{* *} \\
(-42.25)\end{array}$ & $\begin{array}{l}-0.657^{* *} \\
(-41.85)\end{array}$ \\
\hline Job changes & & & & $\begin{array}{l}0.00357^{* *} \\
(4.68)\end{array}$ & & \\
\hline Job changes (1) & & & & & $\begin{array}{l}-0.0159^{* *} \\
(-6.45)\end{array}$ & $\begin{array}{l}-0.0145^{* *} \\
(-5.53)\end{array}$ \\
\hline Job changes (2) & & & & & $\begin{array}{l}0.00124 \\
(0.54)\end{array}$ & $\begin{array}{l}0.00321 \\
(1.28)\end{array}$ \\
\hline Job changes (3) & & & & & $\begin{array}{l}0.0163^{* *} \\
(6.75)\end{array}$ & $\begin{array}{l}0.0177^{* *} \\
(6.66)\end{array}$ \\
\hline Job changes (4) & & & & & $\begin{array}{l}0.0239^{* *} \\
(9.76)\end{array}$ & $\begin{array}{l}0.0253^{* *} \\
(9.44)\end{array}$ \\
\hline Job changes (5) & & & & & $\begin{array}{l}0.00341 \\
(1.61)\end{array}$ & $\begin{array}{l}0.00200 \\
(0.85)\end{array}$ \\
\hline Part-time experience & & & & & & $\begin{array}{l}-0.00583 \\
(-1.66)\end{array}$ \\
\hline Full-time experience & & & & & & $\begin{array}{l}-0.00328 \\
(-1.54)\end{array}$ \\
\hline$N$ & 19,649 & 18,878 & 18,878 & 18,878 & 18,878 & 18,660 \\
\hline
\end{tabular}

NOTE: $t$-statistics are in parentheses. ${ }^{*} p<0.05,{ }^{* *} p<0.01,{ }^{* * *} p<0.001$. 


\section{Table 13}

Average Marginal Effects on Demotion (College)

\begin{tabular}{|c|c|c|c|c|c|c|}
\hline & (1) & (2) & (3) & (4) & (5) & (6) \\
\hline Male & $\begin{array}{l}0.000846 \\
(0.12)\end{array}$ & $\begin{array}{l}0.000978 \\
(0.14)\end{array}$ & $\begin{array}{l}-0.00227 \\
(-0.26)\end{array}$ & $\begin{array}{l}-0.00226 \\
(-0.26)\end{array}$ & $\begin{array}{l}-0.0103 \\
(-1.21)\end{array}$ & $\begin{array}{l}-0.00627 \\
(-0.76)\end{array}$ \\
\hline Age & $\begin{array}{l}0.0137^{* *} \\
(19.62)\end{array}$ & $\begin{array}{l}0.0137^{* *} \\
(19.30)\end{array}$ & $\begin{array}{l}0.00854^{* *} \\
(12.08)\end{array}$ & $\begin{array}{l}0.00872^{* *} \\
(7.80)\end{array}$ & $\begin{array}{l}0.00902^{* *} \\
(8.20)\end{array}$ & $\begin{array}{l}0.00376 \\
(2.44)\end{array}$ \\
\hline AFQT score & & $\begin{array}{l}0.00327 \\
(0.68)\end{array}$ & $\begin{array}{l}-0.0356^{* *} \\
(-5.48)\end{array}$ & $\begin{array}{l}-0.0356^{* *} \\
(-5.50)\end{array}$ & $\begin{array}{l}-0.0268^{* *} \\
(-4.61)\end{array}$ & $\begin{array}{l}-0.0277^{* *} \\
(-4.90)\end{array}$ \\
\hline Hours (yr) & & & $\begin{array}{l}-0.0168 \\
(-1.19)\end{array}$ & $\begin{array}{l}-0.0171 \\
(-1.20)\end{array}$ & $\begin{array}{l}-0.0236 \\
(-1.72)\end{array}$ & $\begin{array}{l}-0.0141 \\
(-1.02)\end{array}$ \\
\hline$\alpha$ & & & $\begin{array}{l}0.513^{* *} \\
(24.28)\end{array}$ & $\begin{array}{l}0.512^{* *} \\
(23.57)\end{array}$ & $\begin{array}{l}0.569^{* *} \\
(26.23)\end{array}$ & $\begin{array}{l}0.567^{* *} \\
(26.24)\end{array}$ \\
\hline Job changes & & & & $\begin{array}{l}-0.000284 \\
(-0.21)\end{array}$ & & \\
\hline Job changes (1) & & & & & $\begin{array}{l}0.0389^{* *} \\
(4.83)\end{array}$ & $\begin{array}{l}0.0368^{* *} \\
(4.72)\end{array}$ \\
\hline Job changes (2) & & & & & $\begin{array}{l}0.0181^{* *} \\
(3.51)\end{array}$ & $\begin{array}{l}0.0148^{*} \\
(2.75)\end{array}$ \\
\hline Job changes (3) & & & & & $\begin{array}{l}0.00764 \\
(2.24)\end{array}$ & $\begin{array}{l}0.00446 \\
(1.26)\end{array}$ \\
\hline Job changes (4) & & & & & $\begin{array}{l}-0.00169 \\
(-0.61)\end{array}$ & $\begin{array}{l}-0.00522 \\
(-1.82)\end{array}$ \\
\hline Job changes (5) & & & & & $\begin{array}{l}-0.0116^{* *} \\
(-6.34)\end{array}$ & $\begin{array}{l}-0.0126^{* *} \\
(-6.69)\end{array}$ \\
\hline Part-time experience & & & & & & $\begin{array}{l}0.0173^{* *} \\
(4.12)\end{array}$ \\
\hline Full-time experience & & & & & & $\begin{array}{l}0.00787^{* *} \\
(4.08)\end{array}$ \\
\hline$N$ & 11,429 & 11,150 & 11,150 & 11,150 & 11,150 & 11,099 \\
\hline
\end{tabular}

NOTE: $t$-statistics are in parentheses. ${ }^{*} p<0.05,{ }^{* *} p<0.01,{ }^{* * *} p<0.001$. 


\section{Canon, Golan, Smith}

\section{Table 14}

Average Marginal Effects on Demotion (No College)

\begin{tabular}{|c|c|c|c|c|c|c|}
\hline & (1) & $(2)$ & (3) & (4) & (5) & (6) \\
\hline Male & $\begin{array}{l}-0.00127 \\
(-0.23)\end{array}$ & $\begin{array}{l}-0.000327 \\
(-0.06)\end{array}$ & $\begin{array}{l}0.0326^{* * *} \\
(4.15)\end{array}$ & $\begin{array}{l}0.0360^{* * *} \\
(4.66)\end{array}$ & $\begin{array}{l}0.0168^{*} \\
(2.25)\end{array}$ & $\begin{array}{l}0.0183^{*} \\
(2.42)\end{array}$ \\
\hline Age & $\begin{array}{l}0.00995^{* * *} \\
(18.24)\end{array}$ & $\begin{array}{l}0.0101^{* * *} \\
(18.16)\end{array}$ & $\begin{array}{l}0.00617^{* * *} \\
(10.27)\end{array}$ & $\begin{array}{l}0.00925^{* * *} \\
(10.11)\end{array}$ & $\begin{array}{l}0.00993^{* * *} \\
(10.48)\end{array}$ & $\begin{array}{l}0.00782^{* * * *} \\
(4.93)\end{array}$ \\
\hline AFQT score & & $\begin{array}{l}0.00516 \\
(-1.68)\end{array}$ & $\begin{array}{l}-0.0331^{* * *} \\
(-8.23)\end{array}$ & $\begin{array}{l}-0.0331^{* * *} \\
(-8.37)\end{array}$ & $\begin{array}{l}-0.0264^{* * *} \\
(-7.04)\end{array}$ & $\begin{array}{l}-0.0270^{* * * *} \\
(-7.15)\end{array}$ \\
\hline Hours (yr) & & & $\begin{array}{l}-0.000117 \\
(-0.01)\end{array}$ & $\begin{array}{l}-0.00386 \\
(-0.33)\end{array}$ & $\begin{array}{l}-0.00236 \\
(-0.19)\end{array}$ & $\begin{array}{l}0.00137 \\
(0.11)\end{array}$ \\
\hline$\alpha$ & & & $\begin{array}{l}0.491^{* * *} \\
(29.61)\end{array}$ & $\begin{array}{l}0.488^{* * * *} \\
(29.89)\end{array}$ & $\begin{array}{l}0.565^{* * *} \\
(34.71)\end{array}$ & $\begin{array}{l}0.564^{* * *} \\
(34.29)\end{array}$ \\
\hline Job changes & & & & $\begin{array}{l}0.00361^{* * *} \\
(-4.86)\end{array}$ & & \\
\hline Job changes (1) & & & & & $\begin{array}{l}0.0165^{* * *} \\
(6.46)\end{array}$ & $\begin{array}{l}0.0154^{* * *} \\
(5.71)\end{array}$ \\
\hline Job changes (2) & & & & & $\begin{array}{l}-0.00215 \\
(-0.94)\end{array}$ & $\begin{array}{l}-0.00388 \\
(-1.58)\end{array}$ \\
\hline Job changes (3) & & & & & $\begin{array}{l}-0.0160^{* * *} \\
(-7.00)\end{array}$ & $\begin{array}{l}-0.0172^{* * *} \\
(-6.83)\end{array}$ \\
\hline Job changes (4) & & & & & $\begin{array}{l}-0.0219^{* * *} \\
(-9.42)\end{array}$ & $\begin{array}{l}-0.0230^{* * *} \\
(-9.06)\end{array}$ \\
\hline Job changes (5) & & & & & $\begin{array}{l}-0.00344 \\
(-1.66)\end{array}$ & $\begin{array}{l}-0.00222 \\
(-0.97)\end{array}$ \\
\hline Part-time experience & & & & & & $\begin{array}{l}0.00572 \\
(1.67)\end{array}$ \\
\hline Full-time experience & & & & & & $\begin{array}{l}0.00281 \\
(1.36)\end{array}$ \\
\hline$N$ & 19,450 & 18,693 & 18,693 & 18,693 & 18,693 & 18,472 \\
\hline
\end{tabular}

NOTE: $t$-statistics are in parentheses. ${ }^{*} p<0.05,{ }^{* *} p<0.01,{ }^{* * *} p<0.001$.

\section{CONCLUSION}

This article documents life-cycle gender differences in the labor market outcomes using longitudinal data of a cohort of individuals, NLSY79. As in other datasets, the gender pay gap increases with age. We find that the gap in weekly hours worked between men and women increases substantially as workers become more experienced. Quantifying the magnitude of the observable variables in the datasets for college- and noncollege-educated workers demonstrates that hours worked is indeed the largest observable variable in the explained gender gap. More than half of the gap is explained by differences in current hours worked and full-time work experience. Adding occupations and pay at the entry-level explains an additional 8 per- 
cent of the gender pay gap between workers with a college degree and decreases by 4 percent the explained gap between workers without a college degree.

These gaps, however, do not reveal the fundamental factors that drive these differences. Hours, experience, and occupations are choices that could be driven by differences in the preferences of men and women (such as time spent at home caring for children) as well as labor market discrimination (see Gayle and Golan, 2011, for a theory in which occupational choice, hours worked, and experience are affected by discrimination).

We then focus on patterns in occupational changes over the life cycle. It is well documented that a large part of wage growth occurs when workers change jobs. We find that collegeeducated men, on average, move into occupations with higher demand for complex tasks and skills, while college-educated women on average do not move into such occupations after the first 2 years in the labor market. $\underline{19}$ We further show that women are less likely to change occupations and that this pattern remains after accounting for other observable differences. Moreover, on average, wages grow when workers change occupations, but on average the growth is smaller for women. We discuss several theories of sorting and turnover consistent with these patterns. Labor market gaps can be the result of differences in the preferences of men and women, a result of allocation of time within the household, as well as discrimination. While it is beyond the scop of this paper to separate these element, these are important questions for us to address in future research.

\section{NOTES}

1 See Blau and Kahn (2017) for a comprehensive review on the trends in the gender wage gap.

2 As shown in Gayle and Golan (2011), estimating for women who work full time continuously, the gender earnings gap declines and ultimately disappears by the time women are in their mid-30s.

3 See Goldin (2014). A model that gives rise endogenously to high returns to working long hours is developed in Gayle and Golan (2011).

4 For example, see Bertrand, Goldin, and Katz (2010) for analysis of women with an MBA and Gayle, Golin, and Miller (2012) for analysis of the market for top executives, among others.

$\underline{5}$ For example, O'Neill (2005) finds that after adding occupations to the wage regression that controls for experience, education and test scores have little effect on the remaining "unexplained" gender pay gap in 2000 for the NLSY79 cohort. Using the PSID data, Blau and Kahn (2017) find that occupation explains one-tenth of the gender wage gap in 1980 and one-third in 2010. There are age differences and differences in variable definitions and controls in the different studies. In this study, we document the evolution of occupational tasks over the life cycle and the role of these changes and occupational transition in the observed gaps.

6 This is consistent with the finding in Gayle and Golan (2011) that the gender hourly wage gap closes and Golan and Hincapié (2016).

1 College major choices tend to be different for men and women partly because certain majors that women choose are associated with greater job flexibility. See Bronson (2014).

8 AFQT scores are routinely used as a measure of cognitive ability.

9 We use the official Bureau of Labor Statistics definition of full-time employment. For robustness, we check other thresholds at five-hour intervals from to 20 to 40 and find that the Bureau of Labor Statistics definition also happens to yield the greatest empirical tractability.

10 Compiled by the Committee on Occupational Classification and Analysis at the National Academy of Sciences. 


\section{Canon, Golan, Smith}

11 We define "consistent" here as 80 percent of weeks.

12 This has been documented for the differences in the median and average wage gaps by Gayle and Golan (2011) and Golan et al. (2016) using PSID data. We document the difference in monthly earnings instead of wages here and explore how it differs by education groups.

13 Another explanation is that there is sample selection. That is, women who work full-time consistently are on average increasingly selected and have higher ability than men with the same pattern of labor supply. Gayle and Golan (2011) account for that factor as well in their structural analysis and find evidence for statistical discrimination.

14 See Blau and Kahn (2017). We deviate by using wages rather than log wages. We also copyedit this passage.

15 Since women's $\alpha$ changes drastically in the first 1.5 years, we also tested defining the entry $\alpha$ as the $\alpha$ after 1 year, and as the maximum $\alpha$ over the first 2 years, but these tests did not change the results substantially.

16 A job change (or turnover) is as any absolute change in $\alpha$ by 0.01 or more.

17 Using data for top executives, Gayle, Limor, and Miller (2012) find that women executives are less likely than men to change firms.

18 A promotion is any $\Delta \alpha>0.05$, that is, more than half a decile.

19 This is not the case for workers without a college degree.

\section{REFERENCES}

Antonovics, Kate and Golan, Limor. "Experimentation and Job Choice." Journal of Labor Economics, 2012, 30(2), pp. 333-66; https://doi.org/10.1086/663356.

Bertrand, Marianne; Goldin, Claudia and Katz, Lawrence F. "Dynamics of the Gender Gap for Young Professionals in the Financial and Corporate Sectors." American Economic Journal: Applied Economics, 2010, 2(3), pp. 228-55; https://doi.org/10.1257/app.2.3.228.

Blau, Francine D. and Kahn, Lawrence M. "The Gender Wage Gap: Extent, Trends, and Explanations." Journal of Economic Literature, 2017, 55(3), pp. 789-865; https://doi.org/10.1257/jel.20160995.

Blinder, Alan S. "Wage Discrimination: Reduced Form and Structural Estimates." Journal of Human Resources, 1973, pp. 436-55; https://doi.org/10.2307/144855.

Bronson, Mary Ann. "Degrees Are Forever: Marriage, Educational Investment, and Lifecycle Labor Decisions of Men and Women." Unpublished manuscript, 2, 2014.

Flabbi, Luca. "Gender Discrimination Estimation in a Search Model with Matching and Bargaining." International Economic Review, 2010, 51(3), pp. 745-83; https://doi.org/10.1111/j.1468-2354.2010.00600.x.

Flabbi, Luca and Mabli, James. "Household Search or Individual Search: Does It Matter?" Journal of Labor Economics, 2018, 36(1), pp. 1-46; https://doi.org/10.1086/693864.

Gayle, George-Levi and Golan, Limor. "Estimating a Dynamic Adverse-Selection Model: Labour-Force Experience and the Changing Gender Earnings Gap 1968-1997." Review of Economic Studies, 2011, 79(1), pp. 227-67; https://doi.org/10.1093/restud/rdr019.

Gayle, George-Levi; Golan, Limor and Miller, Robert A. "Gender Differences in Executive Compensation and Job Mobility." Journal of Labor Economics, 2012, 30(4), pp. 829-72; https://doi.org/10.1086/666615.

Gemici, Ahu. "Family Migration and Labor Market Outcomes." Unpublished manuscript, New York University, 2011.

Golan, Limor and Hincapié, Andrés. "Breaking Down the Gender Wage Gap by Age and by Hours Worked." Federal Reserve Bank of St. Louis Regional Economist, October 2016, pp. 6-13; https://www.stlouisfed.org/ /media/Publications/Regional-Economist/2016/October/gender_wage.pdf.

Golan, Limor and Sanders, Carl. "Racial Gaps, Occupational Matching, and Skill Uncertainty." Federal Reserve Bank of St. Louis Review, Second Quarter 2019, 101(2), pp. 135-53; https://doi.org/10.20955/r.101.135-53. 
Golan, Limor; Sanders, Carl and James, Jonathan. "What Explains the Racial Gaps in Task Assignment and Pay Over the Life-Cycle?" Society for Economic Dynamics, 2019 (Meeting Papers), No. 320.

Goldin, Claudia. "A Grand Gender Convergence: Its Last Chapter." American Economic Review, 2014, 104(4), pp. 1091-19; https://doi.org/10.1257/aer.104.4.1091.

Jovanovic, Boyan. "Job Matching and the Theory of Turnover." Journal of Political Economy, 1979, 87(5, Part 1), pp. 972-90; https://doi.org/10.1086/260808.

Jovanovic, Boyan and Nyarko, Yaw. "Stepping-Stone Mobility," in Carnegie-Rochester Conference Series on Public Policy. Volume 46. Elsevier, 1997, pp. 289-325; https://doi.org/10.1016/S0167-2231(97)00012-2.

Lise, Jeremy and Postel-Vinay, Fabien. "Multidimensional Skills, Sorting, and Human Capital Accumulation." American Economic Review, August 2020, 110(8), pp. 2328-76; https://doi.org/10.1257/aer.20162002.

Miller, Robert A. "Job Matching and Occupational Choice." Journal of Political Economy, 1984, 92(6), pp. 1086-120; https://doi.org/10.1086/261276.

Oaxaca, Ronald. "Male-Female Wage Differentials in Urban Labor Markets." International Economic Review, 1973, pp. 693-709; https://doi.org/10.2307/2525981.

O’Neill, June. "Recent Trends and Current Sources of Gender Wage Gap in the US." 2005.

Taber, Christopher, and Rune Vejlin. "Estimation of a Roy/Search/Compensating Differential Model of the Labor Market." NBER Working paper w22439. National Bureau of Economic Research, 2016; https://doi.org/10.3386/w22439.

U.S. Census Bureau. Dictionary of Occupational Titles. Ann Arbor, MI: Inter-university Consortium for Political and Social Research, 1981; https://occupationalinfo.org.

Yamaguchi, Shintaro. "Tasks and Heterogeneous Human Capital." Journal of Labor Economics, 2012, 30(1), pp. 1-53; https://doi.org/10.1086/662066. 
